\title{
Neuronal Substrate of Eating Disorders
}

Elena Timofeeva and Juliane Calvez

Faculte de Medecine, Departement Psychiatrie et Neurosciences, Centre de recherche de Ilnstitut universitaire de cardiologie et de pneumologie de Quebec, Universite Laval, Quebec (QC), G1V 4G5, Canada

"Corresponding author: Elena Timofeeva, Centre de recherche de IInstitut de cardiologie et de pneumologie de Quebec, Y3150, 2725 Chemin Sainte-Foy, Quebec (QC), Canada, Tel: 418-656-8711; Fax: 418-656-4942; E-mail: Elena.Timofeeva@fmed.ulaval.ca

Received date: Mar 18, 2014, Accepted date: Apr 23, 2014, Published date: Apr 29, 2014

Copyright: (c) 2014 Timofeeva E, et al. This is an open-access article distributed under the terms of the Creative Commons Attribution License, which permits unrestricted use, distribution, and reproduction in any medium, provided the original author and source are credited.

\begin{abstract}
Eating disorders are devastating and life-threatening psychiatric diseases. Although clinical and experimental investigations have significantly progressed in discovering the neuronal causes of eating disorders, the exact neuronal and molecular mechanisms of the development and maintenance of these pathologies are not fully understood. The complexity of the neuronal substrate of eating disorders hampers progress in revealing the precise mechanisms. The present review describes the current knowledge on the implication of the neuronal systems that regulate food intake, stress, emotions, and reward in eating disorders. The current data based on clinical and experimental research strongly suggest that these systems are interconnected and a misbalance in one system leads to altered activity in other food-related regulatory networks.
\end{abstract}

Keywords: Anorexia Nervosa; Bulimia; Binge Eating; Stress; Food Intake; Reward; Hypothalamus; Limbic System; Striatum; Prefrontal Cortex

\begin{abstract}
Abbreviations:
5-HTTLPR: 5HT-Transporter-Linked Polymorphic Region; ABA: Activity-Based Anorexia; ACTH: Adrenocorticotropic Hormone; Agrp: Agouti-Related Peptide; AN: Anorexia Nervosa; AN-BP: Anorexia Nervosa Binge-Purge Subtype; AN-R: Anorexia Nervosa Restrictive Subtype; ARC: Arcuate Nucleus; BED : Binge Eating Disorder; BDNF: Brain-Derived Neurotrophic Factor; BN: Bulimia Nervosa; CART: Cocaine- And Amphetamine-Regulated Transcript; CB1: Cannabinoid Receptor 1; Cea: Central Amygdala; CRF Corticotropin-Releasing Factor; CRF1R: Type 1 CRF Receptor; CRF2R: Type 2 CRF Receptor; CSF: Cerebrospinal Fluid; DMH: Dorsomedial Hypothalamic Nucleus; DRD2: Dopamine Receptor D2; DRD4: Dopamine Receptor D4; DSM-5: Fifth Edition Of The Diagnostic And Statistical Manual Of Mental Disorders; FTO: Fat Mass And Obesity Associated Protein; GABA: Gamma Aminobutyric Acid; HPA: Hypothalamic-Pituitary Adrenal Axis; LH: Lateral Hypothalamus; LS: Lateral Septum; MC4R: Melanocortin 4 Receptor; 5-HT: 5-Hydroxytryptamine; MRI: Magnetic Resonance Imaging; Nacb: Nucleus Accumbens; NPY: Neuropeptide Y; PFC: Prefrontal Cortex; POMC: Proopiomelanocortin; PVN: Paraventricular Hypothalamic Nucleus; PVT: Paraventricular Thalamic Nucleus; VMH: Ventromedial Hypothalamic Nucleus; VTA: Ventral Tegmental Area
\end{abstract}

\section{Introduction}

Eating disorders are severe psychiatric illnesses with a high incidence of psychological and physical comorbidities [1]. The modern food supply of the population of the Western world is characterized by an abundance of high-energy foods [2], eating "comfort" food has become an easy way to relieve increased pressure of everyday stress [3-5]. On another hand, there is also strong cultural pressure for thinness, and various dieting strategies have become very popular [6]. Hence, chronic stress and dieting have been identified as strong antecedents and relapse factors in eating disorders [7-16].

Food intake is controlled by complex, redundant, and distributed neural systems to ensure adequate nutrient supply, homeostatic control, and energy balance. The brain neuronal networks that regulate energy homeostasis and reward are the principal determinants of food intake control, known as homeostatic and hedonic signals, respectively. The homeostatic system is based on biological needs to maintain the body's energy and optimal conditions for biochemical reactions whereas hedonic control is involved in the motivation to eat and is based on pleasure and reward [17-19]. Abnormal changes in the food intake regulatory systems play an important role in triggering and maintaining eating disorders [20], however, the neural substrate underlying these diseases is not yet fully understood.

Clinical and experimental investigations have pointed out the importance of non-homeostatic control of food intake and the neuronal mechanisms that modulate the activity of the brain homeostatic centers in promoting eating in the absence of hunger or inhibiting eating despite hunger in eating disorders. However, the neural substrate underlying these diseases is not yet fully understood. Here we review the physiological, morphological, molecular and genetic abnormalities in the neuronal systems in eating disorders obtained in clinical and experimental research.

\section{General Characteristics of Eating Disorders}

Anorexia nervosa (AN), bulimia nervosa (BN), and binge eating disorder (BED) are three formal eating disorders outlined in the fifth edition of the Diagnostic and Statistical Manual of Mental Disorders (DSM-5) [16]. AN is characterized by self-restriction in energy intake resulting in significant weight loss in concerned individuals. This selfstarvation is associated with an important body image disturbance accompanied by an intense fear of gaining weight or of becoming obese. Individuals suffering from AN can be engaged in recurrent 
episodes of binge eating and purging behavior (AN binge-purge subtype, $\mathrm{AN}-\mathrm{BP}$ ) or not (AN restrictive subtype, $\mathrm{AN}-\mathrm{R}$ ) [16]. $\mathrm{BN}$ is defined by recurrent binge eating episodes followed by either selfinducing vomiting, taking of laxatives, or by some other means to compensate the excess ingested food. As in AN, BN sufferers are characterized by a fear of gaining weight and a distorted body image [16]. BED has more recently been included in the DSM as an eating disorder and is characterized by recurrent episodes of binge eating without compensatory behaviors. Binge eating episodes are characterized by the ingestion of a large amount of food accompanied by a sense of a lack of control over eating [16].

Although $\mathrm{AN}$ and $\mathrm{BN}$ are relatively rare in the general population, they are more common among adolescent girls and young women. According to large population-based studies, AN and BN affect $0.3 \%$ to $0.9 \%$ and $0.8 \%$ to $1.5 \%$ of women (life time prevalence), respectively [21-24]. BN and AN affect women disproportionately more than men, with the female-to-male ratio ranging from $3: 1$ to $10: 1[21,23,25]$. Conversely, $\mathrm{BED}$ is more common for both sexes and in older people, affecting between $1.1 \%$ and $2.8 \%$ of the population [21-24].

The etiopathogenesis of eating disorders is complex and poorly understood, and genetic predisposition and specific environmental factors have been implicated in triggering and maintaining eating disorders $[20,26]$. The common characteristics of AN, BN, and BED are elevated anxiety and deficit in emotion regulation, which are thought to contribute to the development and maintenance of the disorders [27-30]. Clinical research has provided strong evidence that individuals with eating disorders are inclined to use maladaptive strategies to regulate their emotions and distress [29,31]. Among these strategies, inappropriate ingestive behavior such as bingeing or extreme dietary restriction may be used to alleviate or prevent negative emotion, stress, or anxiety [32-34]. Because several physiological contingencies including eating and metabolism as well as emotions, anxiety, and stress are implicated in the etiopathogenesis of eating disorders, the brain systems related to regulating feeding and stress may be involved in triggering eating disorders.

\section{Role of Stress in Eating disorders}

Life stress events often precede the onset of eating disorders whereas chronic stress is associated with the persistence of these disorders $[26,35,36]$. Activity of the stress system is usually altered in subjects suffering from eating disorders [37], and these changes may be closely related to the psychopathological, behavioral, and biological abnormalities found in AN, BN, and BED.

\section{The HPA axis and its interaction with feeding regulatory brain system}

Stress, a "general adaptation syndrome" [38], quickly mobilizes the neuronal, endocrine, and motor systems, which are essential for survival in threatening situations [39]. The stress reaction is regulated by a complex system involving the hypothalamic-pituitary-adrenal (HPA) axis and the sympathetic nervous system. The central component of the HPA axis includes the parvocellular neurons of the paraventricular hypothalamic nucleus $(\mathrm{PVN})$ that produce corticotropin-releasing factor (CRF), which, via the anterior pituitary adrenocorticotropic hormone (ACTH), stimulates the synthesis and release of glucocorticoids (cortisol in humans and corticosterone in rodents) from the adrenal glands (Figure 1). In turn, glucocorticoids signal to the brain to downregulate further activation of the HPA axis
[40-42]. The HPA axis is exquisitely sensitive to perturbations in the external environment and glucocorticoids responses can be initiated by activation of the PVN by nociceptive pathways, recruitment of innate defensive systems or sensory stimuli associated with fear [42-44]. Depending on the stressors, sometimes divided into "systemic" (related to homeostatic threats such as hemorrhages or immune response) and "psychogenic" (related to exteroceptive sensory systems signalling the presence of real or potential danger), specific regions of the brainstem or limbic system activate directly or indirectly the parvocellular PVN neurons that trigger rapid general activation of the HPA axis $[42,43]$.

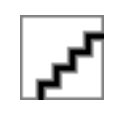

Figure 1: Corticotropin-releasing factor (CRF) mediates the central effects of stress. In response to stress, CRF activates the hypothalamic-pituitary adrenal (HPA) axis via the CRF type 1 receptor (CRF1R) by increasing the synthesis and release of adrenocorticotropic hormone (ACTH) from the anterior pituitary and glucocorticoids (cortisol in humans and corticosterone in rats) from the adrenal glands. The CRF type 2 receptor (CRF2R) mediates the anorectic effects of CRF in the ventromedial hypothalamic nucleus (VMH) and the lateral septum (LS). In addition, activation of the CRF2R in the $\mathrm{VMH}$ activates the energy metabolism, and in the LS increases anxiety. Activity of the VMH is directly related to the homeostatic control of feeding whereas the LS is sensitive to interactive effects of stress and diets.

Activation of the HPA axis is mediated by the type 1 CRF receptor (CRF1R) [45]. In basal, non-stressful conditions, the levels of CRF1R are undetectable in the parvocellular PVN. However, during stress, the CRF1R is strongly expressed by the PVN neurons [46,47]. Induction of expression of CRF1R may be triggered in the PVN by CRF [48], and this CRF auto-regulating mechanism may rapidly intensify activation of the PVN neurons and general activation of the HPA axis during stress. Implication of the CRF1R in stress-induced activation of the HPA axis was demonstrated by inhibiting stress-induced rise in the $\mathrm{ACTH}$ and corticosterone plasma levels in rats treated with a specific CRF1R antagonist [49].

In addition to activating the HPA axis, CRF produces strong anorectic effects [50-53]. In contrast to the inhibition of CRF corticotropic effects by specific CRF1R antagonists, the anorectic effects of CRF are blocked by a specific antagonist of type 2 CRF receptor (CRF2R) but not by a specific CRF1R antagonist [49,54]. If expression of CRF1R is largely distributed in the brain, the expression of the CRF2R is mainly confined to the ventromedial hypothalamic nucleus (VMH) and the lateral septum (LS) [55]. Experimental research involving animal models suggested that the CRF2R in the $\mathrm{VMH}$ is generally involved in the homeostatic control of food intake and energy metabolism (Figure 1) [56,57]. The levels of CRF2R expression in the $\mathrm{VMH}$ are decreased by negative energy balance such as food deprivation [58]. In the LS, activation of the CRF2R mediates stress-induced anxiety and anorexia (Figure 1) [59-61].

The LS is a subcortical brain structure predominantly composed of the inhibitory projection neurons that densely innervate the lateral hypothalamus (LH) and the ventral tegmental area (VTA), brain regions involved in controling food intake [62-66]. Interestingly, a rat 
Page 3 of 15

binge eating model developed by repeated food restriction and stress, showed lower neuronal activation of the LS [67]. The long-term decrease in the activity of the LS inhibitory neurons in this model may result in disinhibition of the LH and VTA neurons. The LH is an important food intake-regulating hypothalamic region closely related to the brain reward system $[68,69]$. Activation of the LH neurons significantly increases motivation to eat as well as stimulates appetitive behavior and enhances reward functions [70-73]. Interestingly, LS lesions enhanced lateral hypothalamic reward sensitivity [74], while LS electrical stimulation counteracted the effects of LH stimulation on feeding [75]. Electrical stimulation of the LS also inhibited a population of the VTA neurons [76]. The VTA contains dopaminergic neurons whose activity codes for the hedonic value of food [77-79] while inactivation of the VTA reduces overconsumption of palatable food [80]. Interestingly, LS lesions significantly enhanced the incentive value of positively rewarding events such as water intake in thirsty rats, salt in sodium-deprived rats, and sucrose in all feeding conditions [66,81-83]. For example, an LS lesion significantly increased sucrose intake but not water intake in non-thirsty rats [81]. The increase in sucrose intake in the LS-lesioned rats was not dependent on hunger because food deprivation and stomach preloading did not affect higher sucrose-eating activity in the LS-lesioned rats [81]. Enhanced motivation for food was revealed in LS-lesioned rats by faster performance speed in food-motivated tasks $[84,85]$. Therefore, the LS is an important modulator of activity of the HPA axis and feeding. Activation of the LS during acute stress may induce anorexia and anxiety, while a decrease in LS activity in binge eating may disinhibit feeding and reward centers in the hypothalamus and midbrain and induce episodes of binge eating.

\section{Interaction between stress and feeding in eating disorders}

Food intake is strongly modulated by stress. Anorectic stress effects are important to stop physiological activities that are not related to stress such as ingestion and digestion, and mobilize all resources for a stress-coping activity (fight or flight). CRF is a potent anorectic peptide involved in stress-induced food intake inhibition $[86,87]$. Conversely, glucocorticoids promote food intake that helps to restore energy resources depleted during stress response [88,89]. Therefore, anorectic-orexigenic regulation of food intake in response to acute stress is very important for survival and adequate maintenance of energy resources. However, misbalance of the HPA axis activity by chronic stress or by an isolate but very strong traumatic experience may produce devastating effects on eating.

Interestingly, evidence of the hyperactivity of the HPA axis was revealed by a significant increase in the basal cortisol levels in patients with AN [90-96] and BN [97-101] (Table 1). This dysregulation may persist in AN after weight gain $[95,96]$ suggesting that the hyperactivity of the HPA axis may be involved in the pathogenesis of the disease. In BED, the results are contradictory showing higher [102] or normal [103] basal cortisol. Following stress exposure, the patients with BED showed a hyperactive [102] or hypoactive [103] response of the HPA axis. However, it is well-established that stress plays a major role in the initiation of binge eating episodes $[33,34,36,104,105]$ and in the maintenance of $\mathrm{BN}[97,106]$. Therefore, imbalance in the HPA axis may lead to the development of eating disorders and may be involved in the maintenance of the diseases [37].

\begin{tabular}{|c|c|c|c|c|c|}
\hline & \multicolumn{2}{|l|}{ Anorexia nervosa } & \multicolumn{3}{|c|}{ Bulimia nervosa and binge eating disorder } \\
\hline & Clinical data & Animal models & Clinical data BN & Clinical data BED & Animal models \\
\hline \multirow[t]{2}{*}{$\begin{array}{l}\text { Stress and } \\
\text { HPA axis }\end{array}$} & \multirow[t]{2}{*}{$\begin{array}{l}\text { HPA } \\
\text { hyperactivity: axis } \\
\uparrow \quad \text { basal plasma } \\
\text { cortisol } \\
\text { Vicious cycle: } \\
\downarrow \text { dysphoric mood } \\
\text { with starvation } \\
\uparrow \text { HPA axis activation } \\
\text { with starvation }\end{array}$} & \multirow[t]{2}{*}{$\begin{array}{l}\text { HPA axis hyperactivity } \\
\text { in ABA model } \\
\uparrow \text { basal corticosterone } \\
\text { Stress-induced } \\
\text { anorexia: } \\
\text { Role of CRF: } \downarrow \text { food } \\
\text { intake via CRF2R } \\
\text { Role of LS: } \downarrow \text { food } \\
\text { intake by } \uparrow \text { activation of } \\
\text { the LS }\end{array}$} & $\begin{array}{l}\text { HPA axis hyperactivity : } \\
\uparrow \text { basal cortisol }\end{array}$ & HPA axis hyperactivity? & $\begin{array}{l}\uparrow \text { binge eating by stress in } \\
\text { animal model with history of } \\
\text { food restriction } \\
\downarrow \text { stress response with } \\
\text { palatable food intake } \\
\uparrow \text { palatable food intake by } \\
\text { glucocorticoids } \\
\uparrow \text { food intake by inhibition of } \\
\text { the LS }\end{array}$ \\
\hline & & & $\begin{array}{l}\text { Vicious cycle: } \\
\uparrow \text { binge eating by stress } \\
\text { Transient } \downarrow \text { dysphoric mood by } \\
\text { binge eating } \\
\uparrow \text { stress by binge eating }\end{array}$ & & \\
\hline $\begin{array}{l}\text { Homeostatic } \\
\text { regulation of } \\
\text { food intake }\end{array}$ & $\begin{array}{lr}\uparrow \text { orexigenic } & \text { (NPY, } \\
\text { ghrelin), } & \downarrow \\
\text { anorexigenic } & \text { factors } \\
\text { (leptin, BDNF) } & \end{array}$ & $\begin{array}{l}\uparrow \quad \text { orexigenic } \\
\text { neuropeptides in ABA } \\
\text { (NPY) } \\
\downarrow \text { anorexigenic factors } \\
\text { in ABA (BDNF) }\end{array}$ & $\begin{array}{l}\text { Impaired hunger suppression after } \\
\text { eating (ghrelin) }\end{array}$ & $\begin{array}{l}\text { Impaired } \\
\text { (ghrelin) }\end{array}$ & $\begin{array}{l}\text { Misbalance in the central } \\
\text { and peripheral modulators } \\
\text { of appetite }\end{array}$ \\
\hline Reward system & $\begin{array}{l}\text { Altered } \quad \text { reward } \\
\text { system: } \\
\begin{array}{l}\text { Dysfunction } \\
\text { dopamine system }\end{array} \\
\begin{array}{l}\text { Starvation } \\
\text { rewarding: }\end{array} \\
\end{array}$ & 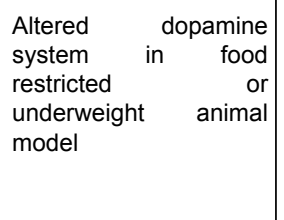 & $\begin{array}{l}\text { Altered reward system: } \\
\downarrow \text { activation of hedonic reward } \\
\text { circuitry } \\
\text { Binge eating as a mean to stimulate } \\
\text { the reward system }\end{array}$ & $\begin{array}{l}\text { Altered reward system: } \\
\uparrow \quad \text { anticipatory } \\
\text { sensitivity which reward } \\
\text { initiation of binge } \\
\text { episode }\end{array}$ & $\begin{array}{l}\uparrow \text { reward system activation } \\
\text { in anticipation of palatable } \\
\text { food intake and during binge } \\
\text { eating episodes } \\
\text { Repeated exposition to } \\
\text { palatable food }\end{array}$ \\
\hline
\end{tabular}




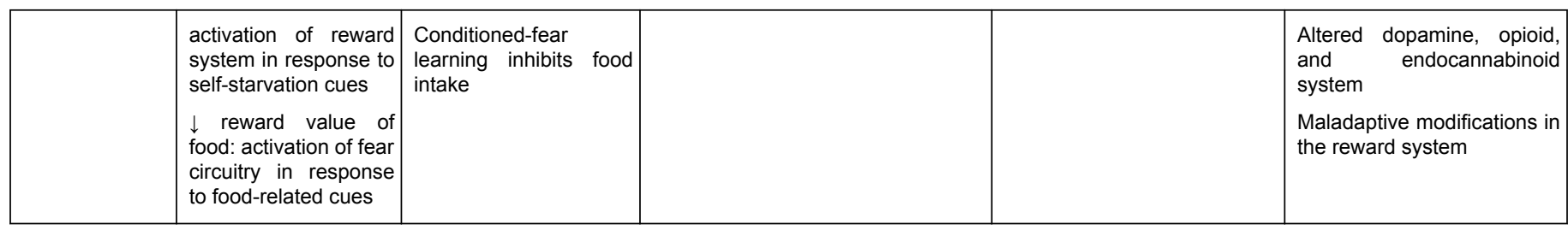

Table 1: Principal alterations in the activity of the hypothalamic-pituitary adrenal (HPA) axis, homeostatic regulation of food intake and reward system in eating disorders

ABA: Activity-based anorexia; AN: Anorexia nervosa; BED: Binge eating disorder; BN: Bulimia nervosa; CRF: Corticotropin-releasing factor; CRF1R: type 1 CRF receptor; CRF2R: type 2 CRF receptor; HPA: Hypothalamic-pituitary-adrenal; LS: Lateral septum; NPY: Neuropeptide Y.

The hyperactivity of the HPA axis in AN [37] was revealed by an increase in the CRF levels in the cerebrospinal fluid (CSF) in patients with AN [91]. The increase in the production and release of CRF may contribute to the manifestation and maintenance of AN by suppressing the appetitive drives [92]. Interestingly, dietary restraint transiently reduced anxiety in AN whereas eating stimulates dysphoric mood [107-109]. These dietary effects were explained by the central serotoninergic system. Individuals recovered from AN showed elevated brain serotonin activity [110] that underpins their chronic state of anxiety and stress [111]. Conversely, dieting or fasting reduced brain serotonin levels $[112,113]$. Therefore, restrictive dietary behavior in AN may be a strategy for achieving a biochemical balance in the brain that helps to transiently decrease anxiety and avoid the dysphoric consequences of eating [32]. However, symptoms of AN such as weight loss, reduced caloric intake, and catabolic state have been shown to have a very powerful influence on the HPA axis [114]. Starvation further increases activation of the HPA axis and dysphoric mood, which might drive further food restriction in a vicious circle [32]. The anorectic effects of CRF [86] may thus be involved in starvation and persistent weight loss in AN [115] whereas starvation might drive further HPA dysregulation $[32,91,116]$.

Similarly as starvation in AN, binge eating seems to relieve stress in $\mathrm{BN}$ and BED. There is strong evidence that restrained and emotional eaters overeat in response to stress [15,117-122]. Furthermore, a shift toward choosing more pleasurable or palatable foods occurred whether or not total caloric intake increased with stress $[119,121,123-125]$. This increase in palatable food intake induced by emotional stress is also demonstrated in rodent models in which choices of sweet and/or fat food were presented following stress exposure [126-130]. Glucocorticoids are involved in stress-induced eating of palatable food [131]. The dose-dependent increase in the intake of palatable food by glucocorticoids has been demonstrated in basal, non-stressful conditions in rats [132-134]. Thus, stress induces secretion of glucocorticoids, which increase motivation for food and promote ingestion of palatable food [131]. In turn, palatable food reduces the magnitude of HPA responses to stress $[128,135,136]$. Indeed, ingestion of palatable food decreased stress-induced rise in the plasma levels of glucocorticoids as well as in induction of the expression of CRF and immediate early gene c-fos in the parvocellular PVN $[67,126,131,137,138]$. When stress promotes glucocorticoidinduced intake of palatable food, an association between the stress relief and the intake of "comfort food" is created to recall this stresscoupling strategy [131]. The exact mechanisms by which palatable food suppresses HPA axis activation are not fully understood. Adding palatable food to the rat diet displaced neuronal food-related activity from the medial hypothalamic regions (including the PVN) that provide homeostatic control of feeding to the reward brain areas $[139,140]$. The reward system stimulated by eating palatable food takes the control of HPA axis activity and food intake [141].

Negative affective states and stress are thought to be the primary causes of binge eating episodes [33,34,104,105,142,143]. Binge eating may thus be an attempt to reduce stress and anxiety with hedonic selfmedication [128,144], and negative feelings are in effect transiently reduced during binge eating $[34,142,145,146]$ or binge-purging episodes [146-149]. However, large meals ingested during binge-eating episodes promote increased secretion of glucocorticoids [97] that overrun the transient "relief" created by palatable food intake and contribute to the chronic state of stress in individuals suffering from $\mathrm{BN}$ and BED. In addition, binge eating or binge-purging episodes are usually followed by feelings of depreciation and guilt in the hours following binge eating $[142,146,148,149]$.

Therefore, in $\mathrm{AN}, \mathrm{BN}$, or $\mathrm{BED}$, stress participates in inducing pathological eating behaviors such as starvation or binge eating. These aberrant eating behavior strategies may be considered as the attempts to cope with stress and decrease the negative affective states by providing short-term relief. However, these aberrant eating strategies impact the long-term maintenance of chronic stress, misbalanced HPA axis activity and eating disorders.

\section{Homeostatic Regulation Of Food Intake In Eating Disorders}

Although BN, AN, and BED are considered eating disorders, it remains unknown whether in these disorders there is a primary disturbance of appetitive function or whether disturbed appetite is secondary to other phenomena, such as anxiety, chronic stress, or nutritional changes that accompany eating disorders [150]. It has been suggested, however, that disturbances in the food intake regulating system may contribute to the maintenance or exacerbation of cycles of food restriction, binge-purge, or binge eating in $\mathrm{AN}, \mathrm{BN}$, and BED as well as affect the response to therapies in these conditions [150].

\section{Neuronal substrate of homeostatic regulation of food intake}

Energy homeostasis regulation involves a coordinated effort between a number of interconnected brain regions including, but not limited to, the hypothalamus and the brainstem. These central regions are accessible to the sensory signals from the taste and digestive systems and to the circulating hormones signaling short-term nutrient availability and long-term energy storage. The brain integrates these 
numerous signals and, in turn, generates relevant behavioral, autonomic, and endocrine output [18].

The hypothalamus plays a crucial role in homeostatic functions [151]. The ventromedial hypothalamus, which consists of the VMH and the arcuate nucleus (ARC), is a key region that integrates satiety (e.g., cholecystokinin, peptide YY, glucagon-like peptide-1, etc.), hunger (e.g., ghrelin) and adiposity (e.g., leptin) signals from the periphery and transmits signals to the forebrain and brainstem areas involved in satiation, neuroendocrine regulation, learning, memory, and reward $[18,19]$. The ARC contains two distinct neuronal populations that produce orexigenic and anorexigenic peptides $[152,153]$. The "anorexigenic" population is located in the lateral subdivision of the ARC and produces anorectic neuropeptides proopiomelanocortin (POMC) and cocaine- and amphetamineregulated transcript (CART) $[154,155]$. The "orexigenic" population of neurons is located in the medial sub-region of the ARC and produces orexigenic neuropeptides agouti-related peptide (AgRP) and neuropeptide Y (NPY) $[156,157]$. The major recipients of the ARC are the PVN-producing anorectic neuropeptide CRF [50], and the LHproducing orexigenic neuropeptides orexin and melaninconcentrating hormone $[18,158]$. The hypothalamic neurons control the activity of the sympathetic and parasympathetic efferents innervating the digestive system via direct innervation of the preganglionic brainstem and spinal cord neurons $[159,160]$.

\section{Dysregulation of appetite hormones and neuropeptides in eating disorders}

Changes in the neuroactive peripheral and central peptides regulating appetite in eating disorders have been extensively studied and reviewed [150,161-163]. Some of the food-intake-regulating molecules (peptides, monoamines, etc.) also interfere with other brain functions such as the reward processes, motivated behaviors, cognition, or emotion whose changes have been reported to contribute to the psychopathological core of eating disorders [16]. Therefore, changes in the central and peripheral components of the feeding regulatory system may not only represent homeostatic adaptation to malnutrition but also contribute to the development and maintenance of aberrant non-homeostatic behaviors of eating disorders, such as starvation or binge eating [163] (Table 1).

In patients with $\mathrm{AN}$, starvation and weight loss correlate with changes in feeding regulatory peptides mainly by an increase in orexigenic peptides and a decrease in anorexigenic peptides as a compensatory mechanism to counteract the negative energy balance [150,161-163]. Plasma leptin levels have been consistently reported to be markedly lower than normal, which was correlated with the patients' body mass index [164-167]. Leptin is an adiposity signal involved in regulating energy balance through stimulating anorexigenic POMC neurons and inhibiting orexigenic NPY/AgRP neurons in the ARC [168]. In AN, general low levels of leptin are accompanied by a disrupted circadian rhythm of leptin [169]. Because leptin generally inhibits HPA axis activity [170], low leptin in AN may contribute to hyperactivity of the HPA axis. Another major abnormality in AN is significantly increased plasma levels of ghrelin at fasting and impaired response to meals [93,161,171-173]. Ghrelin is a stomach hunger hormone that stimulates appetite through activating the NPY neurons in the ARC [174]. The "activity-based anorexia" (ABA) model in rodents [175] reproduces core behavioral correlates of AN like self-restricted food intake in the presence of hunger, hyperactivity, weight loss, and physiological consequences of undernutrition [176]. In this model, it has been shown that mRNA expression of NPY was increased in ARC and that this increase was not correlated with food intake but instead with increased physical activity [177]. In AN, increased CSF NPY was also found [178] and might be involved in the hyperactivity reported in anorectic patients [16]. The ability to maintain restricted eating seems to occur in spite of the physiological hunger signals and hunger feelings [92,179]. The restriction of food intake is voluntary, and non-homeostatic regulation of energy intake seems to override hunger signals at the level of homeostatic control of food intake. Leptin and ghrelin not only act as signals regulating homeostatic feeding driven by metabolic need but also are seemingly involved in modulating the reward system and motivation to obtain food [180]. Leptin suppresses [181,182] and ghrelin activates $[183,184]$ the reward system. In the case of $\mathrm{AN}$, the effects of leptin and ghrelin do not restore the energy balance by increased motivation for food [180], but low leptin and high ghrelin in AN might participate in maintaining starvation as a rewarding behavior [163].

In $\mathrm{BN}$, the role of leptin as a peripheral signal of available energy stores is preserved [163]. Contradictory results exist regarding increased [185] or not [186-188] fasting ghrelin levels in patients with BN. However, postprandial suppression of ghrelin has been reported to be reduced in BN [189-191]. The decrease in plasma ghrelin reflects suppression of hunger signals, and reduced ghrelin suppression after a meal may contribute to the impaired satiety sometimes observed in patients with BN and BED [192,193]. In BED, fasting ghrelin levels are lower than in healthy people $[190,194]$ and plasma ghrelin decreases only slightly after a meal $[194,195]$. Lower levels of plasma ghrelin may contribute to the dysphoric states the frequently occur in BED.

The reduced levels of brain-derived neurotrophic factor (BDNF) have been found in plasma in AN and BN [196,197]. BDNF is an important neuropeptide regulating neuronal survival, development, and functional plasticity in the brain that is also involved in energy homeostasis. In fact, BDNF and its receptor are highly expressed in the brain regions involved in eating behavior and homeostatic control $[198,199]$ while lacking of BDNF or its receptor was associated with hyperphagia and obesity $[200,201]$. Similar to leptin, reduction of BDNF in AN might be seen as a homeostatic adaptative phenomenon aiming to promote food intake in condition of chronic starvation. Moreover, decreased expression of BDNF in the mice model of ABA was linked to increased locomotor activity and decreased motivation to eat [202] suggesting that impaired BDNF transmission in AN might sustain hyperactivity and decreased motivation to eat due to modulating the reward system [163].Eating is co-determined by homeostatic and non-homeostatic neuronal mechanisms. Interaction of these mechanisms seems to play a particularly crucial role in aberrant ingestive behavior in eating disorders $[163,203,204]$.

\section{Cognitive and Hedonic Regulation of Food Intake in Eating Disorders}

\section{The reward circuitry and food intake regulation}

Food intake is a highly motivated behavior and a source of pleasure [205]. Food cues and their hedonic values are linked through learning association and generate motivation to eat. Food-related sensory information (including visual, olfactory, gustatory, and somatosensory signals) is integrated with metabolic cues at the level of the prefrontal cortex (PFC) (e.g. orbitofrontal cortex, anterior cingulate cortex and insular cortex) $[206,207]$. These cortical structures work in an intimate 
interaction with hippocampal formation and the amygdala nuclei to store, update, and retrieve salient information related to food $[18,208,209]$. Food-related activation of the PFC is triggered via several pathways including (i) the paraventricular thalamic nucleus (PVT) that relays signals between the visceral and homeostatic centers of the hypothalamus and the brainstem to the limbic system and (ii) the mesolimbic dopaminergic pathways that originate in the dopaminergic neurons of the VTA that project directly to the nucleus accumbens (NAcb) and the PFC [18,210-214]. In addition to dopamine, activation of opioid, endocannabinoid, as well as GABAergic (GABA for gamma aminobutyric acid) neurotransmission have been associated with food-related hedonic response [206,210]. For example, daily bingeing on sugar repeatedly releases dopamine in the NAcb [215], and activation of the opioid neurotransmission in the $\mathrm{PFC}$ and the NAcb is related to binge-like overeating of highly palatable food [216-218].

Activation of the PFC neurons increases during food reward anticipation and consumption [219,220]. Conversely, optogenetic inhibition of the PFC attenuated stress-induced reinstatement of palatable food seeking [221] and neurotoxic PFC lesions produced impairment in food consumption driven by conditioned motivational cues [222]. Food-restricted rats submitted to scheduled feeding displayed strong activation of the regions of the medial hypothalamus such as the PVN and the dorsomedial hypothalamic nucleus (DMH) when the rats anticipated regular food [140]. Adding sucrose to feeding schedules led to a gradual increase in the daily intake of highly palatable sucrose but not regular chow [139]. Surprisingly, the sucrose-anticipating rats did not show neuronal activation in the medial hypothalamus. In contrast, strong neuronal activation has been detected in the PFC, NAcb, and LH during sucrose anticipation [139]. Therefore, anticipation of regular food activates the medial hypothalamic regions involved in homeostatic control of feeding whereas highly palatable food anticipation activates the brain regions of the reward system, but not the medial hypothalamus (Figure 2).

\section{Brain reward system in eating disorders}

The brain reward system controls eating behavior in close interaction with the neuronal networks involved in emotions, learning, and memory functions. Rewarding and punishing events and the environmental cues associated with these events are learned and memorized by the interactive mechanisms in this distributed network. Food predictive cues can thus stimulate eating despite satiety while fear cues can inhibit eating despite hunger [73]. In eating disorders, food intake regulation via environmental cues produces abnormally low association with reward in patients with $\mathrm{AN}$ and high association with reward in patients with BN and BED [203,223] (Table 1).

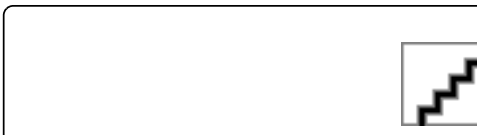

Figure 2: Regular foods and highly palatable foods are anticipated by different parts of the brain. Anticipation of regular food by foodrestricted rats activates the medial hypothalamic regions involved in the homeostatic regulation of food intake such as the paraventricular hypothalamic nucleus $(\mathrm{PVN})$ and the dorsomedial hypothalamic nucleus (DMH). Anticipation of sucrose activates the brain reward system, which includes the prefrontal cortex (PFC), nucleus accumbens (NAcb), and lateral hypothalamus (LH). The paraventricular thalamic nucleus (PVT) is activated by anticipation of both diets and seemingly provides a relay between the homeostatic and reward systems. Excitatory neurotransmission from the PFC to its projecting areas including the NAcb and LH may be facilitated by a decrease in expression of the PFC cannabinoid CB1 receptor by palatable food.

Patients with AN are characterized by a sustained fear of weight gain, and this fear is consequently associated with food and eating [223]. The fear circuitry includes principally the amygdala but also involves the hippocampus, insular cortex, PFC (including the anterior cingulate cortex), and striatum [224]. A meta-analysis of functional magnetic resonance imaging (MRI) studies [225] showed that patients with AN display stronger activation of some regions involved in fear circuitry compared to the control subjects in response to visual food cues [223]. These activations were specific to food. Cues that predict danger, i.e., fear cues, inhibit feeding as part of the coordinated threat and stress response $[209,226]$. The studies of conditioned fear learning in animal models suggested that the central amygdala (CeA) is a critical region for expression of conditioned fear learning [227]. The CeA could exert its action on feeding via direct projections to the brainstem, the $\mathrm{LH}$, and the bed nucleus of the stria terminalis or indirect projections to the PVN [228-231]. Therefore, sustained fear might be an important contributor that facilitates the maintenance of restricted eating in anorexia via the amygdala-hypothalamic network [223,232].

Food is fearful in AN while self-starvation is anxiolytic [107-109] and pathologically rewarding $[116,204]$. Dysfunctions in the reward system that occur in AN [92,204,233,234] may explain the rewarding properties of aberrant eating behaviors. Dysfunction in the dopamine system has been demonstrated in patients with AN [235-237] as well as in animal models of food restriction and weight loss $[238,239]$. Furthermore, cues associated with self-starvation (such as underweight body images) increased ventral striatal activity in AN [240]. These data support the hypothesis that dysfunction in the reward system in AN may be related to an altered dopamine striatal system that can increase the drive for self-starvation. Stress might be implicated in the development and maintenance of starvation dependence in AN [241] since stress-related secretion of glucocorticoids is a known modulator of the ventral striatal dopamine system [242-245]. Therefore, in AN, self-starvation may result from avoidance of food linked to fear circuitry together with a rewarding effect of food restriction.

Accumulating evidence suggests that highly palatable food may promote dependence in some individuals. Similar to drugs of abuse, palatable food can activate the brain reward system, thus producing powerful behavioral reinforcement for this type of food [141,210,246]. Activation of the reward system may be triggered by multiple 
mechanisms. Long-term consumption of highly palatable food in rats significantly decreased expression of the cannabinoid receptor CB1 in the PFC [247]. The CB1 receptor is usually located in the axonal terminals, and activation of the CB1 receptor leads to inhibition of neurotransmitter release $[248,249]$. Since the projecting neurons of the PFC are excitatory glutamatergic neurons, a decrease in CB1 expression in the PFC would facilitate excitatory glutamatergic neurotransmission in the PFC projecting areas which include the NAcb and the LH [250,251]. Activation of the LH neurons expressing orexin may further reinforce feeding motivation via the direct projections to the VTA neurons and activation of the mesolimbic dopamine system $[18,210,252,253]$. Binge eating of sucrose in the rat model produces recurrent dopamine release to the ventral striatum that produce modifications in the mesolimbic dopamine system [215]. Higher activation of the reward centers would escalate the intake of highly palatable food despite creating metabolic and psychological complications [141]. Therefore, repeated stimulation of the reward pathways with highly palatable food leads to neurobiological adaptations that eventually result in compulsive overeating characterized by the frequent drive to initiate eating [254]

An altered reward system is thought to participate in the development and maintenance of pathological binge eating of palatable food in people suffering from eating disorders [255]. Indeed, perturbations of the reward-related brain areas have been demonstrated in patients with BN [256-261]. Decreased activation in the brain regions involved in hedonic evaluation of food (e.g., NAcb; olfactory, cingulate, and insular cortex) [256-258] have led to a hypothesis of hypo-responsiveness of the reward circuitry in BN that might explain the need to eat a large amount of food to stimulate the reward system [223]. In contrast, in BED, food cues presentation induced great activation of the medial olfactory cortex that suggested heightened anticipatory reward sensitivity [261]. Abnormalities in the mesolimbic dopamine and opioid systems in animal models of binge eating support the dysfunctions observed in the reward system in BED [238,262-268]. According to experimental research, an increase in dopamine release to the dorsal striatum was observed in patients with BED during food stimulation [269]. There is also some evidence of higher sensitivity to opioid effects on feeding in BED. Thus, an opioid antagonist decreased the pleasantness and consumption of sweet and high-fat foods in binge eaters, but not in non-bingers [270].

Binge eating is frequently triggered by negative emotions or stress $[33,34,104,105,142,143]$, and negative affect is known to increase the reward value of food in $\mathrm{BN}$ [271]. As mentioned previously, glucocorticoids may trigger the initiation of binge eating mainly through stimulation of the reward system. Glucocorticoids are known modulators of dopaminergic activity in the NAcb [138,272,273]. In addition, glucocorticoids participate in consolidating memory for emotionally arousing experiences [137]. Secretion of opioid and dopamine during stress participates in terminating and attenuating stress response [138,274,275]. Through stimulating the same opioid and dopamine pathways, palatable food may participate in attenuating stress response. This learned association may trigger long-term modifications in the reward system [276]. Therefore, food is naturally rewarding; however, repeated stress and learned association of stress relief and ingestion of palatable food can trigger long-term changes in the brain reward circuitry as well as modulation in reward sensitivity that may lead to pathological binge eating.

\section{Role of Genetic Polymorphisms in Eating Disorders}

Twin and family studies revealed a substantial genetic background in the etiology of $\mathrm{AN}, \mathrm{BN}$ and $\mathrm{BED}$. Thus, impact of heritability ranges from $48 \%$ to $74 \%$ in AN $[277,278]$, from $28 \%$ to $83 \%$ in BN [279] and from $39 \%$ to $57 \%$ in BED $[11,280]$. As previously highlighted, a number of neurotransmitters, hormones and peptides regulating stress response, food intake and reward brain circuitry plays an important role in the etiopathogenesis and maintenance of eating disorders. Extensive molecular genetics studies have been undertaken over the last decades to identify alterations in DNA sequences and gene expression related to the pathogenesis of eating disorders and their symptoms.

The variants of serotonergic genes have been revealed in $\mathrm{AN}, \mathrm{BN}$ and BED. Between them, the high levels of polymorphisms of the 5 HT2A receptor and 5HT-transporter-linked polymorphic region (5HTTLPR) genes were reported for eating disorders. Meta-analyses suggested that polymorphisms of the 5-HT2A [281,282] and 5HTTLPR $[283,284]$ genes were significantly associated with increased risk for AN, whereas no significant associations between 5-HTTLPR polymorphisms and BN were found [283-285]. However, there is evidence that polymorphism in 5-HTTLPR may contribute to the genetic susceptibility to BED [286].

Several studies focusing on dopaminergic mechanisms have linked polymorphism in the D2 (DRD2) and D4 (DRD4) dopamine receptor genes to eating disorders. In some studies [287,288] but not all [289,290], DRD2 and DRD4 polymorphisms displayed a significant association with AN. Similarly, a potential role of DRD2 polymorphisms was found in BED [291]. The brain reward system seems to be altered in eating disorders and increased body of evidence has linked dopamine genes polymorphisms with reward [292-296]. Functional MRI studies in adolescent girls found that polymorphisms of DRD2 and DRD4 were associated with modulated food reward sensitivity [297,298]. In fact, the individuals with high polymorphisms of DRD2 and DRD4 showed weaker responsiveness to food reward and significantly increased risk for unhealthy weight gain [297,298]. Polymorphism of dopamine receptors that renders the reward system less sensitive to dopamine stimulation has been proposed to promote self-stimulatory behavior such as consuming drugs of abuse or binging on foods $[299,300]$. Furthermore, association between polymorphism of the DRD2 gene and obese patients with BED has been demonstrated [291]. The changed sensitivity to reward in binge eating might thus also be linked to genetic variants of the dopamine system.

An association between gene polymorphism of BDNF and eating disorders has also been demonstrated [301]. Heterogeneity in the BDNF DNA sequences has been found in the restricting type of AN and binging/purging type of $\mathrm{BN}$ [301-303]. The fat mass and obesity associated protein (FTO) is a nucleic acid demethylase which is abundantly expressed in all hypothalamic sites regulating feeding behavior [304]. Expression of FTO in the hypothalamic neurons is upregulated by negative energy balance $[305,306]$ while inactivation of the FTO gene in mice protects from obesity [307]. In children a polymorphism in the FTO gene was associated with loss of eating control and frequent selection of energy-dense palatable foods [308]. A polymorphism in the FTO gene was also detected in BN and AN [309], but contradictory results were reported for AN [310]. Mutation in the gene of melanocortin 4 receptor (MC4R) was also associated with BED [311]. Binge eating has been identified as a major phenotypic characteristic of subjects with a mutation in the MC4R $[311,312]$. The MC4R is highly expressed in the hypothalamus and mediates the 
anorectic effects of $\alpha$-melanocyte stimulating hormone, a product of enzymatic cleavage of POMC [313].

In addition, the role of genetic variations in a number of other molecules involved in food intake or body weight regulation (e.g. ghrelin, estrogen, cannabinoid receptors) has been confirmed by some but not all studies [314,315]. The small sample sizes and nonidentified subtypes of eating disorders are frequently in the origin of the controversial results [314,315]. Uncovering of a variety of potential genetic variants involved in eating disorders or their symptoms helps to understand the variability of treatment responses. The research focusing on the genetic causes of eating disorders is important for development of prevention strategies and pertinent timely treatments of eating disorders.

\section{Conclusions}

The neuronal substrate of eating disorders includes interconnecting brain systems that regulate homeostatic energy metabolism, stress response, memory, emotions, and reward. The principal players of the homeostatic system are the medial hypothalamic nuclei integrating the sensory and hormonal signals related to food intake and energy metabolism as well as the specific brainstem nuclei regulating activity of the preganglionic neurons of the autonomic nervous system. Stress response is regulated by the sympathetic nervous system and the HPA axis. The principal hypothalamic nucleus of the HPA axis is the PVN that produces stress-related neurohormone CRF. The anorectic effects of acute stress are mainly mediated by the CRF $2 \mathrm{R}$ in the ventromedial hypothalamus and the lateral septum. The principal memory storage is the hippocampus that via the lateral septum may affect the activity of the homeostatic and reward systems. Emotions are strongly regulated by the amygdala that by their direct and indirect connections may affect activity of the hypothalamic food-intake-regulating nuclei. The reward system includes the mesolimbic pathway with the VTA, prefrontal cortex, and striatum. In addition, the lateral hypothalamus is closely related to the brain reward system. Animal models helped to uncover mechanisms related to stress- and activity-induced anorexia, or stress-induced eating of palatable food in binge eating models. However, the complexity of the neuronal systems related to eating disorders hampers clear understanding of the molecular and neuronal mechanisms of the development and maintenance of these pathologies. Misbalance in one system leads to altered activity in other food-related regulatory networks. For example, hyperactivity of the stress-regulating system affects via peripheral and central stress hormones the activity of the homeostatic system, memory formation, expression of positive and negative emotions, as well as sensitivity of the reward system. However, the reward system may provide certain "relief" from stress by inhibiting the HPA axis, but at the same time the reward system may "hijack" homeostatic control of feeding and favor episodes of binge eating. Implication of multiple brain systems in eating disorders therefore requires a complex strategy for treatment and recovery. After precise diagnostic by a health professional an eating disorder might be treated with particular medication, but also with psychotherapy sessions, dietary consultations, and physical and psychological activities that balance emotions and help with stress.

\section{References}

1. Smink FR, van Hoeken D, Hoek HW (2012) Epidemiology of eating disorders: incidence, prevalence and mortality rates. Curr Psychiatry Rep 14: 406-414.
2. Putnam J, Allshouse J, Kantor LS (2002) U.S. per capita food supply trends: more calories, refined carbohydrates, and fats. FoodReview 25: 2-15.

3. Dallman MF, Pecoraro NC, la Fleur SE (2005) Chronic stress and comfort foods: self-medication and abdominal obesity. Brain Behav Immun 19: 275-280.

4. Davis C, Carter JC (2009) Compulsive overeating as an addiction disorder. A review of theory and evidence. Appetite 53: 1-8.

5. Capasso A, Putrella C, Milano W (2009) Recent clinical aspects of eating disorders. Rev Recent Clin Trials 4: 63-69.

6. Grabe S, Ward LM, Hyde JS (2008) The role of the media in body image concerns among women: a meta-analysis of experimental and correlational studies. Psychol Bull 134: 460-476.

7. Brewerton TD, Dansky BS, Kilpatrick DG, O'Neil PM (2000) Which comes first in the pathogenesis of bulimia nervosa: dieting or bingeing? Int J Eat Disord 28: 259-264.

8. Crowther JH, Sanftner J, Bonifazi DZ, Shepherd KL (2001) The role of daily hassles in binge eating. Int J Eat Disord 29: 449-454.

9. Grilo CM1, Masheb RM, Wilson GT (2001) Subtyping binge eating disorder. J Consult Clin Psychol 69: 1066-1072.

10. Herman CP, Polivy J (1975) Anxiety, restraint, and eating behavior. J Abnorm Psychol 84: 66-72.

11. Mitchell JE, Hatsukami D, Eckert ED, Pyle RL (1985) Characteristics of 275 patients with bulimia. Am J Psychiatry 142: 482-485.

12. Polivy J, Herman CP (1985) Dieting and binging. A causal analysis. Am Psychol 40: 193-201.

13. Polivy J, Herman CP, McFarlane T (1994) Effects of anxiety on eating: does palatability moderate distress-induced overeating in dieters? J Abnorm Psychol 103: 505-510.

14. Stice E, Agras WS, Telch CF, Halmi KA, Mitchell JE, et al. (2001) Subtyping binge eating-disordered women along dieting and negative affect dimensions. Int J Eat Disord 30: 11-27.

15. Greeno CG, Wing RR (1994) Stress-induced eating. Psychol Bull 115 444-464.

16. American Psychiatric Association (2013) Diagnostic and Statistical Manual of Mental Disorders, Fifth Edition. American Psychiatric Association, Arlington, VA.

17. Berridge KC (2009) 'Liking' and 'wanting' food rewards: brain substrates and roles in eating disorders. Physiol Behav 97: 537-550.

18. Berthoud HR, Morrison C (2008) The brain, appetite, and obesity. Annu Rev Psychol 59: 55-92.

19. Richard D, Timofeeva E (2010) Energy balance regulation: complex interplay between the autonomic and cognitive/limbic brains to control food intake and thermogenesis. In: Obesity Prevention: The Role of Brain and Society on Individual Behavior. 299-316. Elsevier, Oxford.

20. Treasure J, Claudino AM, Zucker N (2010) Eating disorders. Lancet 375: 583-593.

21. Hudson JI, Hiripi E, Pope HG Jr, Kessler RC (2007) The prevalence and correlates of eating disorders in the National Comorbidity Survey Replication. Biol Psychiatry 61: 348-358.

22. Kessler RC, Berglund PA, Chiu WT, Deitz AC, Hudson JI, et al. (2013) The prevalence and correlates of binge eating disorder in the World Health Organization World Mental Health Surveys. Biol Psychiatry 73: 904-914.

23. Preti A, Girolamo Gd, Vilagut G, Alonso J, Graaf Rd, et al. (2009) The epidemiology of eating disorders in six European countries: results of the ESEMeD-WMH project. J Psychiatr Res 43: 1125-1132.

24. Swanson SA, Crow SJ, Le Grange D, Swendsen J, Merikangas KR (2011) Prevalence and correlates of eating disorders in adolescents. Results from the national comorbidity survey replication adolescent supplement. Arch Gen Psychiatry 68: 714-723.

25. Hoek HW, van Hoeken D (2003) Review of the prevalence and incidence of eating disorders. Int J Eat Disord 34: 383-396.

26. Jacobi C1, Hayward C, de Zwaan M, Kraemer HC, Agras WS (2004) Coming to terms with risk factors for eating disorders: application of risk 
terminology and suggestions for a general taxonomy. Psychol Bull 130: 19-65.

27. Brockmeyer T, Skunde M2, Wu M2, Bresslein E2, Rudofsky G3, et al. (2014) Difficulties in emotion regulation across the spectrum of eating disorders. Compr Psychiatry 55: 565-571.

28. Danner UN, Sternheim L2, Evers C3 (2014) The importance of distinguishing between the different eating disorders (sub)types when assessing emotion regulation strategies. Psychiatry Res 215: 727-732.

29. Svaldi J, Griepenstroh J, Tuschen-Caffier B, Ehring T (2012) Emotion regulation deficits in eating disorders: a marker of eating pathology or general psychopathology? Psychiatry Res 197: 103-111.

30. Kaye WH, Bulik CM, Thornton L, Barbarich N, Masters K (2004) Comorbidity of anxiety disorders with anorexia and bulimia nervosa. Am J Psychiatry 161: 2215-2221.

31. Aldao A, Nolen-Hoeksema S, Schweizer S (2010) Emotion-regulation strategies across psychopathology: A meta-analytic review. Clin Psychol Rev 30: 217-237.

32. Kaye WH, Fudge JL, Paulus M (2009) New insights into symptoms and neurocircuit function of anorexia nervosa. Nat Rev Neurosci 10: 573-584.

33. Crosby RD, Wonderlich SA, Engel SG, Simonich H, Smyth J, et al. (2009) Daily mood patterns and bulimic behaviors in the natural environment. Behav Res Ther 47: 181-188.

34. Smyth JM, Wonderlich SA, Heron KE, Sliwinski MJ, Crosby RD, et al. (2007) Daily and momentary mood and stress are associated with binge eating and vomiting in bulimia nervosa patients in the natural environment. J Consult Clin Psychol 75: 629-638.

35. Rojo L, Conesa L, Bermudez O, Livianos L (2006) Influence of stress in the onset of eating disorders: data from a two-stage epidemiologic controlled study. Psychosom Med 68: 628-635.

36. Pike KM, Wilfley D, Hilbert A, Fairburn CG, Dohm FA, et al. (2006) Antecedent life events of binge-eating disorder. Psychiatry Res 142: 19-29.

37. Lo Sauro C, Ravaldi C, Cabras PL, Faravelli C, Ricca V (2008) Stress, hypothalamic-pituitary-adrenal axis and eating disorders. Neuropsychobiology 57: 95-115.

38. Selye H (1975) Stress and distress. Compr Ther 1: 9-13.

39. Ulrich-Lai YM, Herman JP (2009) Neural regulation of endocrine and autonomic stress responses. Nat Rev Neurosci 10: 397-409.

40. Dallman MF, Akana SF, Levin N, Walker CD, Bradbury MJ, et al. (1994) Corticosteroids and the control of function in the hypothalamopituitary-adrenal (HPA) axis. Ann N Y Acad Sci 746: 22-31.

41. Herman JP, Cullinan WE (1997) Neurocircuitry of stress: central control of the hypothalamo-pituitary-adrenocortical axis. Trends Neurosci 20: 78-84.

42. Sawchenko PE1, Li HY, Ericsson A (2000) Circuits and mechanisms governing hypothalamic responses to stress: a tale of two paradigms. Prog Brain Res 122: 61-78.

43. Herman JP, Figueiredo H, Mueller NK, Ulrich-Lai Y, Ostrander MM, et al. (2003) Central mechanisms of stress integration: hierarchical circuitry controlling hypothalamo-pituitary-adrenocortical responsiveness. Front Neuroendocrinol 24: 151-180

44. Herman JP, Ostrander MM, Mueller NK, Figueiredo H (2005) Limbic system mechanisms of stress regulation: hypothalamo-pituitaryadrenocortical axis. Prog Neuropsychopharmacol Biol Psychiatry 29: 1201-1213.

45. Nikodemova M, Diehl CR, Aguilera G (2002) Multiple sites of control of type-1 corticotropin releasing hormone receptor levels in the pituitary. Arch Physiol Biochem 110: 123-128.

46. Timofeeva E, Huang Q, Richard D (2003) Effects of treadmill running on brain activation and the corticotropin-releasing hormone system. Neuroendocrinology 77: 388-405.

47. Rivest S, Laflamme N, Nappi RE (1995) Immune challenge and immobilization stress induce transcription of the gene encoding the CRF receptor in selective nuclei of the rat hypothalamus. J Neurosci 15: 2680-2695.
48. Mansi JA, Rivest S, Drolet G (1996) Regulation of corticotropin-releasing factor type 1 (CRF1) receptor messenger ribonucleic acid in the paraventricular nucleus of rat hypothalamus by exogenous CRF. Endocrinology 137: 4619-4629.

49. Ohata H, Arai K, Shibasaki T (2002) Effect of chronic administration of a CRF(1) receptor antagonist, CRA1000, on locomotor activity and endocrine responses to stress. Eur J Pharmacol 457: 201-206.

50. Richard D, Timofeeva E (2009) Energy Homeostasis: Paraventricular Nucleus (PVN) System. In: Encyclopedia of Neuroscience. 1035-1041. Elsevier, Berlin.

51. Richard D (1999) The role of corticotropin-releasing hormone in the regulation of energy balance. Curr Opin Endocrinol Diabetes 6: 10-19.

52. Richard D (1993) Involvement of corticotropin-releasing factor in the control of food intake and energy expenditure. Ann N Y Acad Sci 697: 155-172.

53. Rivest S, Richard D (1990) Involvement of corticotropin-releasing factor in the anorexia induced by exercise. Brain Res Bull 25: 169-172.

54. Pelleymounter MA, Joppa M, Carmouche M, Cullen MJ, Brown B, et al. (2000) Role of corticotropin-releasing factor (CRF) receptors in the anorexic syndrome induced by CRF. J Pharmacol Exp Ther 293: 799-806.

55. Chalmers DT, Lovenberg TW, De Souza EB (1995) Localization of novel corticotropin-releasing factor receptor (CRF2) mRNA expression to specific subcortical nuclei in rat brain: comparison with CRF1 receptor mRNA expression. J Neurosci 15: 6340-6350.

56. Chao H, Digruccio M, Chen P, Li C (2012) Type 2 corticotropinreleasing factor receptor in the ventromedial nucleus of hypothalamus is critical in regulating feeding and lipid metabolism in white adipose tissue. Endocrinology 153: 166-176.

57. Chen P, Hover CV, Lindberg D, Li C (2012) Central urocortin 3 and type 2 corticotropin-releasing factor receptor in the regulation of energy homeostasis: critical involvement of the ventromedial hypothalamus. Front Endocrinol (Lausanne) 3: 180.

58. Timofeeva E1, Richard D (1997) Functional activation of CRH neurons and expression of the genes encoding $\mathrm{CRH}$ and its receptors in fooddeprived lean $(\mathrm{Fa} /$ ? $)$ and obese $(\mathrm{fa} / \mathrm{fa})$ Zucker rats. Neuroendocrinology 66: 327-340.

59. Wang C1, Kotz CM (2002) Urocortin in the lateral septal area modulates feeding induced by orexin A in the lateral hypothalamus. Am J Physiol Regul Integr Comp Physiol 283: R358-367.

60. Bakshi VP, Newman SM, Smith-Roe S, Jochman KA, Kalin NH (2007) Stimulation of lateral septum CRF2 receptors promotes anorexia and stress-like behaviors: functional homology to CRF1 receptors in basolateral amygdala. J Neurosci 27: 10568-10577.

61. Anthony TE1, Dee N2, Bernard A2, Lerchner W1, Heintz N3, et al. (2014) Control of stress-induced persistent anxiety by an extra-amygdala septohypothalamic circuit. Cell 156: 522-536.

62. Swanson LW, Risold PY (2000) On the basic architecture of the septal region. In: The Behavioral Neuroscience of the Septal Region. 1-14. Springer, NY.

63. Risold PY, Swanson LW (1997) Connections of the rat lateral septal complex. Brain Res Brain Res Rev 24: 115-195.

64. Risold PY, Swanson LW (1997) Chemoarchitecture of the rat lateral septal nucleus. Brain Res Brain Res Rev 24: 91-113.

65. Swanson LW, Cowan WM (1979) The connections of the septal region in the rat. J Comp Neurol 186: 621-655.

66. Sheehan TP, Chambers RA, Russell DS (2004) Regulation of affect by the lateral septum: implications for neuropsychiatry. Brain Res Brain Res Rev 46: 71-117.

67. Martin J, Timofeeva E (2010) Intermittent access to sucrose increases sucrose-licking activity and attenuates restraint stress-induced activation of the lateral septum. Am J Physiol Regul Integr Comp Physiol 298: 1383-1398.

68. Harris GC, Wimmer M, Aston-Jones G (2005) A role for lateral hypothalamic orexin neurons in reward seeking. Nature 437: 556-559. 
69. DiLeone RJ, Georgescu D, Nestler EJ (2003) Lateral hypothalamic neuropeptides in reward and drug addiction. Life Sci 73: 759-768.

70. Stanley BG, Urstadt KR, Charles JR, Kee T (2011) Glutamate and GABA in lateral hypothalamic mechanisms controlling food intake. Physiol Behav 104: 40-46.

71. Scammell TE, Saper CB (2005) Orexin, drugs and motivated behaviors. Nat Neurosci 8: 1286-1288.

72. Berthoud HR, Münzberg H (2011) The lateral hypothalamus as integrator of metabolic and environmental needs: from electrical selfstimulation to opto-genetics. Physiol Behav 104: 29-39.

73. Petrovich GD (2011) Learning and the motivation to eat: forebrain circuitry. Physiol Behav 104: 582-589.

74. Keesey RE, Powley TL (1968) Enhanced lateral hypothalamic reward sensitivity following septal lesions in the rat. Physiol Behav 3: 557-562.

75. Oliveira LA, Gentil CG, Covian MR (1990) Role of the septal area in feeding behavior elicited by electrical stimulation of the lateral hypothalamus of the rat. Braz J Med Biol Res 23: 49-58.

76. Maeda H, Mogenson GJ (1981) Electrophysiological responses of neurons of the ventral tegmental area to electrical stimulation of amygdala and lateral septum. Neuroscience 6: 367-376.

77. Schultz W (1998) Predictive reward signal of dopamine neurons. J Neurophysiol 80: 1-27.

78. Mirenowicz J, Schultz W (1996) Preferential activation of midbrain dopamine neurons by appetitive rather than aversive stimuli. Nature 379 : 449-451.

79. Schultz W (2001) Reward signaling by dopamine neurons. Neuroscientist 7: 293-302.

80. Shimura T, Kamada Y, Yamamoto T (2002) Ventral tegmental lesions reduce overconsumption of normally preferred taste fluid in rats. Behav Brain Res 134: 123-130.

81. Beatty WW, Schwartzbaum JS (1968) Consummatory behavior for sucrose following septal lesions in the rat. J Comp Physiol Psychol 65: 93-102.

82. Blass EM, Nussbaum AI, Hanson DG (1974) Septal hyperdipsia: specific enhancement of drinking to angiotensin in rats. J Comp Physiol Psychol 87: 422-439.

83. Vasudev R, Gentil CG, Covian MR (1985) Taste preferences in a freechoice situation following electrical stimulation and lesion of septal area in rats. Physiol Behav 34: 619-624.

84. Schwartzbaum JS, Donovick PJ (1968) Discrimination reversal and spatial alternation associated with septal and caudate dysfunction in rats. J Comp Physiol Psychol 65: 83-92.

85. Henke PG (1974) Persistence of runway performance after septal lesions in rats. J Comp Physiol Psychol 86: 760-767.

86. Krahn DD, Gosnell BA, Grace M, Levine AS (1986) CRF antagonist partially reverses CRF- and stress-induced effects on feeding. Brain Res Bull 17: 285-289.

87. Smagin GN, Howell LA, Redmann S Jr, Ryan DH, Harris RB (1999) Prevention of stress-induced weight loss by third ventricle CRF receptor antagonist. Am J Physiol 276: R1461-1468.

88. Dallman MF, la Fleur SE, Pecoraro NC, Gomez F, Houshyar H, et al. (2004) Minireview: glucocorticoids--food intake, abdominal obesity, and wealthy nations in 2004. Endocrinology 145: 2633-2638.

89. Takeda E, Terao J, Nakaya Y, Miyamoto K, Baba Y, et al. (2004) Stress control and human nutrition. J Med Invest 51: 139-145.

90. dos Santos E, dos Santos JE, Ribeiro RP, Rosa E Silva AC, Moreira AC, et al. (2007) Absence of circadian salivary cortisol rhythm in women with anorexia nervosa. J Pediatr Adolesc Gynecol 20: 13-18.

91. Kaye WH, Gwirtsman HE, George DT, Ebert MH, Jimerson DC, et al. (1987) Elevated cerebrospinal fluid levels of immunoreactive corticotropin-releasing hormone in anorexia nervosa: relation to state of nutrition, adrenal function, and intensity of depression. J Clin Endocrinol Metab 64: 203-208.

92. Lawson EA, Holsen LM, Desanti R, Santin M, Meenaghan E, et al. (2013) Increased hypothalamic-pituitary-adrenal drive is associated with decreased appetite and hypoactivation of food-motivation neurocircuitry in anorexia nervosa. Eur J Endocrinol 169: 639-647.

93. Misra M, Miller KK, Almazan C, Ramaswamy K, Lapcharoensap W, et al. (2004) Alterations in cortisol secretory dynamics in adolescent girls with anorexia nervosa and effects on bone metabolism. J Clin Endocrinol Metab 89: 4972-4980.

94. Putignano P, Dubini A, Toja P, Invitti C, Bonfanti S, et al. (2001) Salivary cortisol measurement in normal-weight, obese and anorexic women: comparison with plasma cortisol. Eur J Endocrinol 145: 165-171.

95. Grinspoon S, Thomas L, Miller K, Pitts S, Herzog D, et al. (2001) Changes in regional fat redistribution and the effects of estrogen during spontaneous weight gain in women with anorexia nervosa. Am J Clin Nutr 73: 865-869.

96. Mayer L, Walsh BT, Pierson RN Jr, Heymsfield SB, Gallagher D, et al. (2005) Body fat redistribution after weight gain in women with anorexia nervosa. Am J Clin Nutr 81: 1286-1291.

97. Kaye WH, Gwirtsman HE, George DT (1989) The effect of bingeing and vomiting on hormonal secretion. Biol Psychiatry 25: 768-780.

98. Monteleone P, Maes M, Fabrazzo M, Tortorella A, Lin A, et al. (1999) Immunoendocrine findings in patients with eating disorders. Neuropsychobiology 40: 115-120.

99. Copeland PM, Herzog DB, Carr DB, Klibanski A, MacLaughlin RA, et al. (1988) Effect of dexamethasone on cortisol and prolactin responses to meals in bulimic and normal women. Psychoneuroendocrinology 13: 273-278.

100. Bruce KR, Steiger H, Israël M, Groleau P, Ng Ying Kin NM, et al. (2012) Cortisol responses on the dexamethasone suppression test among women with Bulimia-spectrum eating disorders: associations with clinical symptoms. Prog Neuropsychopharmacol Biol Psychiatry 38: 241-246.

101. Koo-Loeb JH, Pedersen C, Girdler SS (1998) Blunted cardiovascular and catecholamine stress reactivity in women with bulimia nervosa. Psychiatry Res 80: 13-27.

102. Gluck ME, Geliebter A, Lorence M (2004) Cortisol stress response is positively correlated with central obesity in obese women with binge eating disorder (BED) before and after cognitive-behavioral treatment. Ann N Y Acad Sci 1032: 202-207.

103. Rosenberg N, Bloch M, Ben Avi I, Rouach V, Schreiber S, et al. (2013) Cortisol response and desire to binge following psychological stress: comparison between obese subjects with and without binge eating disorder. Psychiatry Res 208: 156-161.

104. Lingswiler VM, Crowther JH, Stephens MA (1987) Emotional reactivity and eating in binge eating and obesity. J Behav Med 10: 287-299.

105. Telch CF, Agras WS (1996) Do emotional states influence binge eating in the obese? Int J Eat Disord 20: 271-279.

106. Cattanach L, Malley R, Rodin J (1988) Psychologic and physiologic reactivity to stressors in eating disordered individuals. Psychosom Med 50: 591-599.

107. Kaye WH, Barbarich NC, Putnam K, Gendall KA, Fernstrom J, et al. (2003) Anxiolytic effects of acute tryptophan depletion in anorexia nervosa. Int J Eat Disord 33: 257-267.

108. Frank GK, Kaye WH (2012) Current status of functional imaging in eating disorders. Int J Eat Disord 45: 723-736.

109. Vitousek K, Manke F (1994) Personality variables and disorders in anorexia nervosa and bulimia nervosa. J Abnorm Psychol 103: 137-147.

110. Bailer UF, Kaye WH (2011) Serotonin: imaging findings in eating disorders. Curr Top Behav Neurosci 6: 59-79.

111. Chaouloff F, Berton O, Mormède P (1999) Serotonin and stress. Neuropsychopharmacology 21: 28S-32S.

112. Anderson IM, Parry-Billings M, Newsholme EA, Fairburn CG, Cowen PJ (1990) Dieting reduces plasma tryptophan and alters brain 5-HT function in women. Psychol Med 20: 785-791.

113. Haleem DJ, Haider S (1996) Food restriction decreases serotonin and its synthesis rate in the hypothalamus. Neuroreport 7: 1153-1156. 
Page 11 of 15

114. Fichter MM, Pirke KM (1986) Effect of experimental and pathological weight loss upon the hypothalamo-pituitary-adrenal axis. Psychoneuroendocrinology 11: 295-305.

115. Connan F, Lightman SL, Landau S, Wheeler M, Treasure J, et al. (2007) An investigation of hypothalamic-pituitary-adrenal axis hyperactivity in anorexia nervosa: the role of CRH and AVP. J Psychiatr Res 41: 131-143.

116. Bergh C, Södersten P (1996) Anorexia nervosa, self-starvation and the reward of stress. Nat Med 2: 21-22.

117. Habhab S, Sheldon JP, Loeb RC (2009) The relationship between stress, dietary restraint, and food preferences in women. Appetite 52: 437-444.

118. Wardle J, Steptoe A, Oliver G, Lipsey Z (2000) Stress, dietary restraint and food intake. J Psychosom Res 48: 195-202.

119. Oliver G1, Wardle J (1999) Perceived effects of stress on food choice. Physiol Behav 66: 511-515.

120. Rutters F, Nieuwenhuizen AG, Lemmens SG, Born JM, WesterterpPlantenga MS (2009) Acute stress-related changes in eating in the absence of hunger. Obesity (Silver Spring) 17: 72-77.

121. Zellner DA, Loaiza S, Gonzalez Z, Pita J, Morales J, et al. (2006) Food selection changes under stress. Physiol Behav 87: 789-793.

122. Wallis DJ, Hetherington MM (2004) Stress and eating: the effects of egothreat and cognitive demand on food intake in restrained and emotional eaters. Appetite 43: 39-46.

123. Gibson EL (2006) Emotional influences on food choice: sensory, physiological and psychological pathways. Physiol Behav 89: 53-61.

124. Oliver G, Wardle J, Gibson EL (2000) Stress and food choice: a laboratory study. Psychosom Med 62: 853-865.

125. Warne JP (2009) Shaping the stress response: interplay of palatable food choices, glucocorticoids, insulin and abdominal obesity. Mol Cell Endocrinol 300: 137-146.

126. Foster MT, Warne JP, Ginsberg AB, Horneman HF, Pecoraro NC, et al. (2009) Palatable foods, stress, and energy stores sculpt corticotropinreleasing factor, adrenocorticotropin, and corticosterone concentrations after restraint. Endocrinology 150: 2325-2333.

127. la Fleur SE, Houshyar H, Roy M, Dallman MF (2005) Choice of lard, but not total lard calories, damps adrenocorticotropin responses to restraint. Endocrinology 146: 2193-2199.

128. Pecoraro N, Reyes F, Gomez F, Bhargava A, Dallman MF (2004) Chronic stress promotes palatable feeding, which reduces signs of stress: feedforward and feedback effects of chronic stress. Endocrinology 145: 3754-3762.

129. Teegarden SL, Bale TL (2008) Effects of stress on dietary preference and intake are dependent on access and stress sensitivity. Physiol Behav 93: 713-723.

130. Hagan MM, Wauford PK, Chandler PC, Jarrett LA, Rybak RJ, et al. (2002) A new animal model of binge eating: key synergistic role of past caloric restriction and stress. Physiol Behav 77: 45-54.

131. Dallman MF (2010) Stress-induced obesity and the emotional nervous system. Trends Endocrinol Metab 21: 159-165.

132. la Fleur SE, Akana SF, Manalo SL, Dallman MF (2004) Interaction between corticosterone and insulin in obesity: regulation of lard intake and fat stores. Endocrinology 145: 2174-2185.

133. Bhatnagar S, Bell ME, Liang J, Soriano L, Nagy TR, et al. (2000) Corticosterone facilitates saccharin intake in adrenalectomized rats: does corticosterone increase stimulus salience? J Neuroendocrinol 12: 453-460.

134. Bell ME, Bhatnagar S, Liang J, Soriano L, Nagy TR, et al. (2000) Voluntary sucrose ingestion, like corticosterone replacement, prevents the metabolic deficits of adrenalectomy. J Neuroendocrinol 12: 461-470.

135. Bell ME, Bhargava A, Soriano L, Laugero K, Akana SF, et al. (2002) Sucrose intake and corticosterone interact with cold to modulate ingestive behaviour, energy balance, autonomic outflow and neuroendocrine responses during chronic stress. J Neuroendocrinol 14: 330-342.
136. Kinzig KP, Hargrave SL, Honors MA (2008) Binge-type eating attenuates corticosterone and hypophagic responses to restraint stress. Physiol Behav 95: 108-113.

137. Roozendaal B, McEwen BS, Chattarji S (2009) Stress, memory and the amygdala. Nat Rev Neurosci 10: 423-433.

138. Dallman MF, Pecoraro NC, La Fleur SE, Warne JP, Ginsberg AB, et al. (2006) Glucocorticoids, chronic stress, and obesity. Prog Brain Res 153: 75-105.

139. Mitra A, Lenglos C, Martin J, Mbende N, Gagné A, et al. (2011) Sucrose modifies c-fos mRNA expression in the brain of rats maintained on feeding schedules. Neuroscience 192: 459-474.

140. Poulin AM, Timofeeva E (2008) The dynamics of neuronal activation during food anticipation and feeding in the brain of food-entrained rats. Brain Res 1227: 128-141.

141. Timofeeva E, Mitra A (2013) The effects of sucrose on neuronal activity. In: Sucrose, Properties, Biosynthesis and Health Implication. 75-114. Nova Science Publishers, NY.

142. Abraham SF, Beumont PJ (1982) How patients describe bulimia or binge eating. Psychol Med 12: 625-635.

143. Johnson C, Larson R (1982) Bulimia: an analysis of moods and behavior. Psychosom Med 44: 341-351.

144. Dallman MF, Akana SF, Laugero KD, Gomez F, Manalo S, et al. (2003) A spoonful of sugar: feedback signals of energy stores and corticosterone regulate responses to chronic stress. Physiol Behav 79: 3-12.

145. Kaye WH, Gwirtsman HE, George DT, Weiss SR, Jimerson DC (1986) Relationship of mood alterations to bingeing behaviour in bulimia. Br J Psychiatry 149: 479-485.

146. Haedt-Matt AA, Keel PK (2011) Revisiting the affect regulation model of binge eating: a meta-analysis of studies using ecological momentary assessment. Psychol Bull 137: 660-681.

147. Alpers GW, Tuschen-Caffier B (2001) Negative feelings and the desire to eat in bulimia nervosa. Eat Behav 2: 339-352.

148. Corstorphine E, Waller G, Ohanian V, Baker M (2006) Changes in internal states across the binge-vomit cycle in bulimia nervosa. J Nerv Ment Dis 194: 446-449.

149. Powell AL, Thelen MH (1996) Emotions and cognitions associated with bingeing and weight control behavior in bulimia. J Psychosom Res 40: $317-328$

150. Monteleone P, Castaldo E, Maj M (2008) Neuroendocrine dysregulation of food intake in eating disorders. Regul Pept 149: 39-50.

151. Berthoud HR (2002) Multiple neural systems controlling food intake and body weight. Neurosci Biobehav Rev 26: 393-428.

152. Baskin DG, Figlewicz Lattemann D, Seeley RJ, Woods SC, Porte D Jr, et al. (1999) Insulin and leptin: dual adiposity signals to the brain for the regulation of food intake and body weight. Brain Res 848: 114-123.

153. Varela L, Horvath TL (2012) Leptin and insulin pathways in POMC and AgRP neurons that modulate energy balance and glucose homeostasis. EMBO Rep 13: 1079-1086.

154. Kristensen P, Judge ME, Thim L, Ribel U, Christjansen KN, et al. (1998) Hypothalamic CART is a new anorectic peptide regulated by leptin. Nature 393: 72-76.

155. Williams KW1, Margatho LO, Lee CE, Choi M, Lee S, et al. (2010) Segregation of acute leptin and insulin effects in distinct populations of arcuate proopiomelanocortin neurons. J Neurosci 30: 2472-2479.

156. Wang Q, Liu C, Uchida A1, Chuang JC1, Walker A2, et al. (2013) Arcuate AgRP neurons mediate orexigenic and glucoregulatory actions of ghrelin. Mol Metab 3: 64-72.

157. Schwartz MW, Woods SC, Porte D Jr, Seeley RJ, Baskin DG (2000) Central nervous system control of food intake. Nature 404: 661-671.

158. Barson JR, Morganstern I, Leibowitz SF (2013) Complementary roles of orexin and melanin-concentrating hormone in feeding behavior. Int J Endocrinol 2013: 983964.

159. Shahar T, Palkovits M (2007) Cross over of forebrain and brainstem neuronal projections to spinal cord sympathetic preganglionic neurons in the rat. Stress 10: 145-152. 
160. Portillo F, Carrasco M, Vallo JJ (1996) Hypothalamic neuron projection to autonomic preganglionic levels related with glucose metabolism: a fluorescent labelling study in the rat. Neurosci Lett 210: 197-200.

161. Prince AC, Brooks SJ, Stahl D, Treasure J (2009) Systematic review and meta-analysis of the baseline concentrations and physiologic responses of gut hormones to food in eating disorders. Am J Clin Nutr 89: 755-765.

162. Smitka K, Papezova H, Vondra K, Hill M, Hainer V, et al. (2013) The Role of "Mixed" Orexigenic and Anorexigenic Signals and Autoantibodies Reacting with Appetite-Regulating Neuropeptides and Peptides of the Adipose Tissue-Gut-Brain Axis: Relevance to Food Intake and Nutritional Status in Patients with Anorexia Nervosa and Bulimia Nervosa. Int J Endocrinol 2013: 483145.

163. Monteleone P, Maj M (2013) Dysfunctions of leptin, ghrelin, BDNF and endocannabinoids in eating disorders: beyond the homeostatic control of food intake. Psychoneuroendocrinology 38: 312-330.

164. Dostálová I, Kopský V, Dusková J, Papezová H, Pacák K, et al. (2005) Leptin concentrations in the abdominal subcutaneous adipose tissue of patients with anorexia nervosa assessed by in vivo microdialysis. Regul Pept 128: 63-68.

165. Hebebrand J, Blum WF, Barth N, Coners H, Englaro P, et al. (1997) Leptin levels in patients with anorexia nervosa are reduced in the acute stage and elevated upon short-term weight restoration. Mol Psychiatry 2: 330-334.

166. Lob S, Pickel J, Bidlingmaier M, Schaaf L, Backmund H, et al. (2003) Serum leptin monitoring in anorectic patients during refeeding therapy. Exp Clin Endocrinol Diabetes 111: 278-282.

167. Monteleone P, Di Lieto A, Tortorella A, Longobardi N, Maj M (2000) Circulating leptin in patients with anorexia nervosa, bulimia nervosa or binge-eating disorder: relationship to body weight, eating patterns, psychopathology and endocrine changes. Psychiatry Res 94: 121-129.

168. Blundell JE, Goodson S, Halford JC (2001) Regulation of appetite: role of leptin in signalling systems for drive and satiety. Int J Obes Relat Metab Disord 25 Suppl 1: S29-34.

169. Balligand JL, Brichard SM, Brichard V, Desager JP, Lambert M (1998) Hypoleptinemia in patients with anorexia nervosa: loss of circadian rhythm and unresponsiveness to short-term refeeding. Eur J Endocrinol 138: 415-420.

170. Roubos EW, Dahmen M, Kozicz T, Xu L (2012) Leptin and the hypothalamo-pituitary-adrenal stress axis. Gen Comp Endocrinol 177: 28-36.

171. Tanaka M, Tatebe Y, Nakahara T, Yasuhara D, Sagiyama K, et al. (2003) Eating pattern and the effect of oral glucose on ghrelin and insulin secretion in patients with anorexia nervosa. Clin Endocrinol (Oxf) 59: 574-579.

172. Nedvídková J, Krykorková I, Barták V, Papezová H, Gold PW, et al. (2003) Loss of meal-induced decrease in plasma ghrelin levels in patients with anorexia nervosa. J Clin Endocrinol Metab 88: 1678-1682.

173. Stock S1, Leichner P, Wong AC, Ghatei MA, Kieffer TJ, et al. (2005) Ghrelin, peptide YY, glucose-dependent insulinotropic polypeptide, and hunger responses to a mixed meal in anorexic, obese, and control female adolescents. J Clin Endocrinol Metab 90: 2161-2168.

174. Murphy KG1, Bloom SR (2006) Gut hormones and the regulation of energy homeostasis. Nature 444: 854-859.

175. Routtenberg A, Kuznesof AW (1967) Self-starvation of rats living in activity wheels on a restricted feeding schedule. J Comp Physiol Psychol 64: 414-421.

176. Ploog DW, Pirke KM (1987) Psychobiology of anorexia nervosa. Psychol Med 17: 843-859.

177. Nergårdh R, Ammar A, Brodin U, Bergström J, Scheurink A, et al. (2007) Neuropeptide Y facilitates activity-based-anorexia. Psychoneuroendocrinology 32: 493-502.

178. Kaye WH, Berrettini W, Gwirtsman H, George DT (1990) Altered cerebrospinal fluid neuropeptide $\mathrm{Y}$ and peptide $\mathrm{YY}$ immunoreactivity in anorexia and bulimia nervosa. Arch Gen Psychiatry 47: 548-556.
179. Garfinkel PE (1974) Perception of hunger and satiety in anorexia nervosa. Psychol Med 4: 309-315.

180. Lockie SH, Andrews ZB (2013) The hormonal signature of energy deficit: Increasing the value of food reward. Mol Metab 2: 329-336.

181. Davis JF, Choi DL, Schurdak JD, Fitzgerald MF, Clegg DJ, et al. (2011) Leptin regulates energy balance and motivation through action at distinct neural circuits. Biol Psychiatry 69: 668-674.

182. Krügel U, Schraft T, Kittner H, Kiess W, Illes P (2003) Basal and feedingevoked dopamine release in the rat nucleus accumbens is depressed by leptin. Eur J Pharmacol 482: 185-187.

183. Jerlhag E, Egecioglu E, Dickson SL, Douhan A, Svensson L, et al. (2007) Ghrelin administration into tegmental areas stimulates locomotor activity and increases extracellular concentration of dopamine in the nucleus accumbens. Addict Biol 12: 6-16.

184. Abizaid A, Liu ZW, Andrews ZB, Shanabrough M, Borok E, et al. (2006) Ghrelin modulates the activity and synaptic input organization of midbrain dopamine neurons while promoting appetite. J Clin Invest 116: 3229-3239.

185. Tanaka M, Naruo T, Nagai N, Kuroki N, Shiiya T, et al. (2003) Habitual binge/purge behavior influences circulating ghrelin levels in eating disorders. J Psychiatr Res 37: 17-22.

186. Monteleone P, Martiadis V, Rigamonti AE, Fabrazzo M, Giordani C, et al. (2005) Investigation of peptide YY and ghrelin responses to a test meal in bulimia nervosa. Biol Psychiatry 57: 926-931.

187. Nakazato M, Hashimoto K, Shiina A, Koizumi H, Mitsumoti M, et al. (2004) No changes in serum ghrelin levels in female patients with bulimia nervosa. Prog Neuropsychopharmacol Biol Psychiatry 28: 1181-1184.

188. Troisi A, Di Lorenzo G, Lega I, Tesauro M, Bertoli A, et al. (2005) Plasma ghrelin in anorexia, bulimia, and binge-eating disorder: relations with eating patterns and circulating concentrations of cortisol and thyroid hormones. Neuroendocrinology 81: 259-266.

189. Kojima S, Nakahara T, Nagai N, Muranaga T, Tanaka M, et al. (2005) Altered ghrelin and peptide YY responses to meals in bulimia nervosa. Clin Endocrinol (Oxf) 62: 74-78.

190. Monteleone P, Fabrazzo M, Tortorella A, Martiadis V, Serritella C, et al. (2005) Circulating ghrelin is decreased in non-obese and obese women with binge eating disorder as well as in obese non-binge eating women, but not in patients with bulimia nervosa. Psychoneuroendocrinology 30: 243-250

191. Monteleone P, Martiadis V, Fabrazzo M, Serritella C, Maj M (2003) Ghrelin and leptin responses to food ingestion in bulimia nervosa: implications for binge-eating and compensatory behaviours. Psychol Med 33: 1387-1394.

192. Kissileff HR, Wentzlaff TH, Guss JL, Walsh BT, Devlin MJ, et al. (1996) A direct measure of satiety disturbance in patients with bulimia nervosa. Physiol Behav 60: 1077-1085.

193. Owen WP, Halmi KA, Gibbs J, Smith GP (1985) Satiety responses in eating disorders. J Psychiatr Res 19: 279-284.

194. Geliebter A, Gluck ME, Hashim SA (2005) Plasma ghrelin concentrations are lower in binge-eating disorder. J Nutr 135: 1326-1330.

195. Geliebter A, Yahav EK, Gluck ME, Hashim SA (2004) Gastric capacity, test meal intake, and appetitive hormones in binge eating disorder. Physiol Behav 81: 735-740.

196. Brandys MK, Kas MJ, van Elburg AA, Campbell IC, Adan RA (2011) A meta-analysis of circulating BDNF concentrations in anorexia nervosa. World J Biol Psychiatry 12: 444-454.

197. Phillips K, Keane K2, Wolfe BE3 (2014) Peripheral Brain Derived Neurotrophic Factor (BDNF) in Bulimia Nervosa: A Systematic Review. Arch Psychiatr Nurs 28: 108-113.

198. Rios M, Fan G, Fekete C, Kelly J, Bates B, et al. (2001) Conditional deletion of brain-derived neurotrophic factor in the postnatal brain leads to obesity and hyperactivity. Mol Endocrinol 15: 1748-1757.

199. Tsao D, Thomsen HK, Chou J, Stratton J, Hagen M, et al. (2008) TrkB agonists ameliorate obesity and associated metabolic conditions in mice. Endocrinology 149: 1038-1048. 
Page 13 of 15

200. Bariohay B, Lebrun B, Moyse E, Jean A (2005) Brain-derived neurotrophic factor plays a role as an anorexigenic factor in the dorsal vagal complex. Endocrinology 146: 5612-5620.

201. Wang C, Bomberg E, Billington C, Levine A, Kotz CM (2007) Brainderived neurotrophic factor in the hypothalamic paraventricular nucleus reduces energy intake. Am J Physiol Regul Integr Comp Physiol 293: 1003-1012.

202. Gelegen C, van den Heuvel J, Collier DA, Campbell IC, Oppelaar H, et al. (2008) Dopaminergic and brain-derived neurotrophic factor signalling in inbred mice exposed to a restricted feeding schedule. Genes Brain Behav 7: 552-559.

203. Kaye WH, Wierenga CE, Bailer UF, Simmons AN, Wagner A, et al. (2013) Does a shared neurobiology for foods and drugs of abuse contribute to extremes of food ingestion in anorexia and bulimia nervosa? Biol Psychiatry 73: 836-842.

204. Keating C, Tilbrook AJ, Rossell SL, Enticott PG, Fitzgerald PB (2012) Reward processing in anorexia nervosa. Neuropsychologia 50: 567-575.

205. Berridge KC (2004) Motivation concepts in behavioral neuroscience. Physiol Behav 81: 179-209.

206. Berridge KC, Ho CY, Richard JM, DiFeliceantonio AG (2010) The tempted brain eats: pleasure and desire circuits in obesity and eating disorders. Brain Res 1350: 43-64.

207. Rolls ET (2012) Taste, olfactory and food texture reward processing in the brain and the control of appetite. Proc Nutr Soc 71: 488-501.

208. Berthoud HR (2012) The neurobiology of food intake in an obesogenic environment. Proc Nutr Soc 71: 478-487.

209. Petrovich GD (2013) Forebrain networks and the control of feeding by environmental learned cues. Physiol Behav 121: 10-18.

210. Kelley AE, Baldo BA, Pratt WE, Will MJ (2005) Corticostriatalhypothalamic circuitry and food motivation: integration of energy, action and reward. Physiol Behav 86: 773-795.

211. Timofeeva E, Baraboi ED, Richard D (2005) Contribution of the vagus nerve and lamina terminalis to brain activation induced by refeeding. Eur J Neurosci 22: 1489-1501.

212. Meye FJ, Adan RA2 (2014) Feelings about food: the ventral tegmental area in food reward and emotional eating. Trends Pharmacol Sci 35: 31-40.

213. Pinto A, Jankowski M, Sesack SR (2003) Projections from the paraventricular nucleus of the thalamus to the rat prefrontal cortex and nucleus accumbens shell: ultrastructural characteristics and spatial relationships with dopamine afferents. J Comp Neurol 459: 142-155.

214. Bubser M, Deutch AY (1998) Thalamic paraventricular nucleus neurons collateralize to innervate the prefrontal cortex and nucleus accumbens. Brain Res 787: 304-310.

215. Rada P, Avena NM, Hoebel BG (2005) Daily bingeing on sugar repeatedly releases dopamine in the accumbens shell. Neuroscience 134: 737-744.

216. Blasio A, Steardo L, Sabino V, Cottone P (2013) Opioid system in the medial prefrontal cortex mediates binge-like eating. Addict Biol .

217. Colantuoni C, Rada P, McCarthy J, Patten C, Avena NM, et al. (2002) Evidence that intermittent, excessive sugar intake causes endogenous opioid dependence. Obes Res 10: 478-488.

218. Spangler R, Wittkowski KM, Goddard NL, Avena NM, Hoebel BG, et al. (2004) Opiate-like effects of sugar on gene expression in reward areas of the rat brain. Brain Res Mol Brain Res 124: 134-142.

219. Horst NK, Laubach M (2013) Reward-related activity in the medial prefrontal cortex is driven by consumption. Front Neurosci 7: 56.

220. Petykó Z, Tóth A, Szabó I, Gálosi R, Lénárd L (2009) Neuronal activity in rat medial prefrontal cortex during sucrose solution intake. Neuroreport 20: 1235-1239.

221. Calu DJ, Kawa AB, Marchant NJ, Navarre BM, Henderson MJ, et al. (2013) Optogenetic inhibition of dorsal medial prefrontal cortex attenuates stress-induced reinstatement of palatable food seeking in female rats. J Neurosci 33: 214-226.
222. Petrovich GD, Ross CA, Holland PC, Gallagher M (2007) Medial prefrontal cortex is necessary for an appetitive contextual conditioned stimulus to promote eating in sated rats. J Neurosci 27: 6436-6441.

223. Friederich HC, Wu M, Simon JJ, Herzog W (2013) Neurocircuit function in eating disorders. Int J Eat Disord 46: 425-432.

224. Shin LM, Liberzon I (2010) The neurocircuitry of fear, stress, and anxiety disorders. Neuropsychopharmacology 35: 169-191.

225. Zhu Y, Hu X, Wang J, Chen J, Guo Q, et al. (2012) Processing of food, body and emotional stimuli in anorexia nervosa: a systematic review and meta-analysis of functional magnetic resonance imaging studies. Eur Eat Disord Rev 20: 439-450.

226. Veling H, Aarts H, Stroebe W (2011) Fear signals inhibit impulsive behavior toward rewarding food objects. Appetite 56: 643-648.

227. Petrovich GD, Ross CA, Mody P, Holland PC, Gallagher M (2009) Central, but not basolateral, amygdala is critical for control of feeding by aversive learned cues. J Neurosci 29: 15205-15212.

228. Dong HW, Petrovich GD, Swanson LW (2001) Topography of projections from amygdala to bed nuclei of the stria terminalis. Brain Res Brain Res Rev 38: 192-246.

229. Hahn JD, Swanson LW (2010) Distinct patterns of neuronal inputs and outputs of the juxtaparaventricular and suprafornical regions of the lateral hypothalamic area in the male rat. Brain Res Rev 64: 14-103.

230. Prewitt CM, Herman JP (1998) Anatomical interactions between the central amygdaloid nucleus and the hypothalamic paraventricular nucleus of the rat: a dual tract-tracing analysis. J Chem Neuroanat 15: 173-185.

231. Swanson LW, Petrovich GD (1998) What is the amygdala? Trends Neurosci 21: 323-331.

232. Strober M (2004) Pathologic fear conditioning and anorexia nervosa: on the search for novel paradigms. Int J Eat Disord 35: 504-508.

233. Holsen LM, Lawson EA, Blum J, Ko E, Makris N, et al. (2012) Food motivation circuitry hypoactivation related to hedonic and nonhedonic aspects of hunger and satiety in women with active anorexia nervosa and weight-restored women with anorexia nervosa. J Psychiatry Neurosci 37: 322-332.

234. Jappe LM, Frank GK, Shott ME, Rollin MD, Pryor T, et al. (2011) Heightened sensitivity to reward and punishment in anorexia nervosa. Int J Eat Disord 44: 317-324.

235. Barbato G, Fichele M, Senatore I, Casiello M, Muscettola G (2006) Increased dopaminergic activity in restricting-type anorexia nervosa. Psychiatry Res 142: 253-255.

236. Frank GK, Bailer UF, Henry SE, Drevets W, Meltzer CC, et al. (2005) Increased dopamine D2/D3 receptor binding after recovery from anorexia nervosa measured by positron emission tomography and [11c] raclopride. Biol Psychiatry 58: 908-912.

237. Kaye WH, Frank GK, McConaha C (1999) Altered dopamine activity after recovery from restricting-type anorexia nervosa. Neuropsychopharmacology 21: 503-506.

238. Avena NM, Rada P, Hoebel BG (2008) Underweight rats have enhanced dopamine release and blunted acetylcholine response in the nucleus accumbens while bingeing on sucrose. Neuroscience 156: 865-871.

239. Carr KD, Tsimberg Y, Berman Y, Yamamoto N (2003) Evidence of increased dopamine receptor signaling in food-restricted rats. Neuroscience 119: 1157-1167.

240. Fladung AK, Grön G, Grammer K, Herrnberger B, Schilly E, et al. (2010) A neural signature of anorexia nervosa in the ventral striatal reward system. Am J Psychiatry 167: 206-212.

241. Zink CF, Weinberger DR (2010) Cracking the moody brain: the rewards of self starvation. Nat Med 16: 1382-1383.

242. Abercrombie ED, Keefe KA, DiFrischia DS, Zigmond MJ (1989) Differential effect of stress on in vivo dopamine release in striatum, nucleus accumbens, and medial frontal cortex. J Neurochem 52: 1655-1658. 
Page 14 of 15

243. Barr AM, Brotto LA, Phillips AG (2000) Chronic corticosterone enhances the rewarding effect of hypothalamic self-stimulation in rats. Brain Res 875: 196-201.

244. Goeders NE (2002) Stress and cocaine addiction. J Pharmacol Exp Ther 301: 785-789.

245. Sarnyai Z, McKittrick CR, McEwen BS, Kreek MJ (1998) Selective regulation of dopamine transporter binding in the shell of the nucleus accumbens by adrenalectomy and corticosterone-replacement. Synapse 30: 334-337.

246. Cota D, Tschöp MH, Horvath TL, Levine AS (2006) Cannabinoids, opioids and eating behavior: the molecular face of hedonism? Brain Res Rev 51: 85-107.

247. Timofeeva E, Baraboi ED, Poulin AM, Richard D (2009) Palatable highenergy diet decreases the expression of cannabinoid type 1 receptor messenger RNA in specific brain regions in the rat. J Neuroendocrinol 21: 982-992.

248. Gerdeman G, Lovinger DM (2001) CB1 cannabinoid receptor inhibits synaptic release of glutamate in rat dorsolateral striatum. J Neurophysiol 85: 468-471.

249. Sidhpura N, Parsons LH (2011) Endocannabinoid-mediated synaptic plasticity and addiction-related behavior. Neuropharmacology 61: 1070-1087.

250. Rempel-Clower NL, Barbas H (1998) Topographic organization of connections between the hypothalamus and prefrontal cortex in the rhesus monkey. J Comp Neurol 398: 393-419.

251. Sesack SR, Deutch AY, Roth RH, Bunney BS (1989) Topographical organization of the efferent projections of the medial prefrontal cortex in the rat: an anterograde tract-tracing study with Phaseolus vulgaris leucoagglutinin. J Comp Neurol 290: 213-242.

252. Calipari ES, España RA (2012) Hypocretin/orexin regulation of dopamine signaling: implications for reward and reinforcement mechanisms. Front Behav Neurosci 6: 54.

253. Quarta D, Smolders I (2014) Rewarding, reinforcing and incentive salient events involve orexigenic hypothalamic neuropeptides regulating mesolimbic dopaminergic neurotransmission. Eur J Pharm Sci.

254. Volkow ND, Wise RA (2005) How can drug addiction help us understand obesity? Nat Neurosci 8: 555-560.

255. Adam TC, Epel ES (2007) Stress, eating and the reward system. Physiol Behav 91: 449-458.

256. Bohon C, Stice E (2011) Reward abnormalities among women with full and subthreshold bulimia nervosa: a functional magnetic resonance imaging study. Int J Eat Disord 44: 585-595.

257. Frank GK, Reynolds JR, Shott ME, O'Reilly RC (2011) Altered temporal difference learning in bulimia nervosa. Biol Psychiatry 70: 728-735.

258. Frank GK, Wagner A, Achenbach S, McConaha C, Skovira K, et al. (2006) Altered brain activity in women recovered from bulimic-type eating disorders after a glucose challenge: a pilot study. Int J Eat Disord 39: 76-79.

259. Brooks SJ, O'Daly OG, Uher R, Friederich HC, Giampietro V, et al. (2011) Differential neural responses to food images in women with bulimia versus anorexia nervosa. PLoS One 6: e22259.

260. Kim KR, Ku J, Lee JH, Lee H, Jung YC (2012) Functional and effective connectivity of anterior insula in anorexia nervosa and bulimia nervosa. Neurosci Lett 521: 152-157.

261. Schienle A, Schäfer A, Hermann A, Vaitl D (2009) Binge-eating disorder: reward sensitivity and brain activation to images of food. Biol Psychiatry 65: 654-661.

262. Avena NM, Bocarsly ME (2012) Dysregulation of brain reward systems in eating disorders: neurochemical information from animal models of binge eating, bulimia nervosa, and anorexia nervosa. Neuropharmacology 63: 87-96.

263. Avena NM1, Rada P, Hoebel BG (2008) Evidence for sugar addiction: behavioral and neurochemical effects of intermittent, excessive sugar intake. Neurosci Biobehav Rev 32: 20-39.
264. Bello NT, Sweigart KL, Lakoski JM, Norgren R, Hajnal A (2003) Restricted feeding with scheduled sucrose access results in an upregulation of the rat dopamine transporter. Am J Physiol Regul Integr Comp Physiol 284: R1260-1268.

265. Colantuoni C, Schwenker J, McCarthy J, Rada P, Ladenheim B, et al. (2001) Excessive sugar intake alters binding to dopamine and mu-opioid receptors in the brain. Neuroreport 12:3549-3552.

266. Kelley AE, Will MJ, Steininger TL, Zhang M, Haber SN (2003) Restricted daily consumption of a highly palatable food (chocolate Ensure(R)) alters striatal enkephalin gene expression. Eur J Neurosci 18: 2592-2598.

267. Corwin RL, Woinicki FH (2009) Baclofen, raclopride, and naltrexone differentially affect intake of fat and sucrose under limited access conditions. Behav Pharmacol 20: 537-548.

268. Jarosz PA, Metzger BL (2002) The effect of opioid antagonism on food intake behavior and body weight in a biobehavioral model of obese binge eating. Biol Res Nurs 3: 198-209.

269. Wang GJ, Geliebter A, Volkow ND, Telang FW, Logan J, et al. (2011) Enhanced striatal dopamine release during food stimulation in binge eating disorder. Obesity (Silver Spring) 19: 1601-1608.

270. Drewnowski A, Krahn DD, Demitrack MA, Nairn K, Gosnell BA (1995) Naloxone, an opiate blocker, reduces the consumption of sweet high-fat foods in obese and lean female binge eaters. Am J Clin Nutr 61: 1206-1212.

271. Bohon C, Stice E (2012) Negative affect and neural response to palatable food intake in bulimia nervosa. Appetite 58: 964-970.

272. Barrot M, Abrous DN, Marinelli M, Rougé-Pont F, Le Moal M, et al. (2001) Influence of glucocorticoids on dopaminergic transmission in the rat dorsolateral striatum. Eur J Neurosci 13: 812-818.

273. Czyrak A, MaÄłkowiak M, Chocyk A, Fijå̊, K, Wedzony K (2003) Role of glucocorticoids in the regulation of dopaminergic neurotransmission. Pol J Pharmacol 55: 667-674.

274. Drolet G, Dumont EC, Gosselin I, Kinkead R, Laforest S, et al. (2001) Role of endogenous opioid system in the regulation of the stress response. Prog Neuropsychopharmacol Biol Psychiatry 25: 729-741.

275. Kalivas PW, Duffy P (1995) Selective activation of dopamine transmission in the shell of the nucleus accumbens by stress. Brain Res 675: 325-328.

276. Nanni G, Scheggi S, Leggio B, Grappi S, Masi F, et al. (2003) Acquisition of an appetitive behavior prevents development of stress-induced neurochemical modifications in rat nucleus accumbens. J Neurosci Res 73: 573-580.

277. Klump KL, Miller KB, Keel PK, McGue M, Iacono WG (2001) Genetic and environmental influences on anorexia nervosa syndromes in a population-based twin sample. Psychol Med 31: 737-740.

278. Kortegaard LS, Hoerder K, Joergensen J, Gillberg C, Kyvik KO (2001) A preliminary population-based twin study of self-reported eating disorder. Psychol Med 31: 361-365.

279. Bulik CM, Sullivan PF, Wade TD, Kendler KS (2000) Twin studies of eating disorders: a review. Int J Eat Disord 27: 1-20.

280. Javaras KN, Laird NM, Reichborn-Kjennerud T, Bulik CM, Pope HG Jr, et al. (2008) Familiality and heritability of binge eating disorder: results of a case-control family study and a twin study. Int J Eat Disord 41: 174-179.

281. Gorwood P, Kipman A, Foulon C (2003) The human genetics of anorexia nervosa. Eur J Pharmacol 480: 163-170.

282. Martásková D, Slachtová L, Kemlink D, Záhoráková D, Papezová H (2009) Polymorphisms in serotonin-related genes in anorexia nervosa. The first study in Czech population and metaanalyses with previously performed studies. Folia Biol (Praha) 55: 192-197.

283. Calati R, De Ronchi D, Bellini M, Serretti A (2011) The 5-HTTLPR polymorphism and eating disorders: a meta-analysis. Int J Eat Disord 44: 191-199.

284. Lee Y, Lin PY (2010) Association between serotonin transporter gene polymorphism and eating disorders: a meta-analytic study. Int J Eat Disord 43: 498-504. 
285. Polsinelli GN, Levitan RN, De Luca V (2012) 5-HTTLPR polymorphism in bulimia nervosa: a multiple-model meta-analysis. Psychiatr Genet 22: 219-225.

286. Monteleone P, Tortorella A, Castaldo E, Maj M (2006) Association of a functional serotonin transporter gene polymorphism with binge eating disorder. Am J Med Genet B Neuropsychiatr Genet 141B: 7-9.

287. Bachner-Melman R, Lerer E, Zohar AH, Kremer I, Elizur Y, et al. (2007) Anorexia nervosa, perfectionism, and dopamine D4 receptor (DRD4). Am J Med Genet B Neuropsychiatr Genet 144B: 748-756.

288. Bergen AW, Yeager M, Welch RA, Haque K, Ganjei JK, et al. (2005) Association of multiple DRD2 polymorphisms with anorexia nervosa. Neuropsychopharmacology 30: 1703-1710.

289. Hinney A, Schneider J, Ziegler A, Lehmkuhl G, Poustka F, et al. (1999) No evidence for involvement of polymorphisms of the dopamine D4 receptor gene in anorexia nervosa, underweight, and obesity. Am J Med Genet 88: 594-597.

290. Nisoli E, Brunani A, Borgomainerio E, Tonello C, Dioni L, et al. (2007) D2 dopamine receptor (DRD2) gene Taq1A polymorphism and the eating-related psychological traits in eating disorders (anorexia nervosa and bulimia) and obesity. Eat Weight Disord 12: 91-96.

291. Davis C, Levitan RD, Yilmaz Z, Kaplan AS, Carter JC, et al. (2012) Binge eating disorder and the dopamine D2 receptor: genotypes and subphenotypes. Prog Neuropsychopharmacol Biol Psychiatry 38: 328-335.

292. Camara E, Krämer UM, Cunillera T, Marco-Pallarés J, Cucurell D, et al. (2010) The effects of COMT (Val108/158Met) and DRD4 (SNP -521) dopamine genotypes on brain activations related to valence and magnitude of rewards. Cereb Cortex 20: 1985-1996.

293. Dreher JC, Kohn P, Kolachana B, Weinberger DR, Berman KF (2009) Variation in dopamine genes influences responsivity of the human reward system. Proc Natl Acad Sci U S A 106: 617-622.

294. Forbes EE, Brown SM, Kimak M, Ferrell RE, Manuck SB, et al. (2009) Genetic variation in components of dopamine neurotransmission impacts ventral striatal reactivity associated with impulsivity. Mol Psychiatry 14: 60-70.

295. Peciña M, Mickey BJ, Love T, Wang H, Langenecker SA, et al. (2013) DRD2 polymorphisms modulate reward and emotion processing dopamine neurotransmission and openness to experience. Cortex 49: 877-890.

296. Schmack K, Schlagenhauf F, Sterzer P, Wrase J, Beck A, et al. (2008) Catechol-O-methyltransferase val158met genotype influences neural processing of reward anticipation. Neuroimage 42: 1631-1638.

297. Stice E, Spoor S, Bohon C, Small DM (2008) Relation between obesity and blunted striatal response to food is moderated by TaqIA A1 allele. Science 322: 449-452.

298. Stice E, Yokum S, Bohon C, Marti N, Smolen A (2010) Reward circuitry responsivity to food predicts future increases in body mass: moderating effects of DRD2 and DRD4. Neuroimage 50: 1618-1625.

299. Comings DE, Blum K (2000) Reward deficiency syndrome: genetic aspects of behavioral disorders. Prog Brain Res 126: 325-341.
300. Noble EP (2000) Addiction and its reward process through polymorphisms of the D2 dopamine receptor gene: a review. Eur Psychiatry 15: 79-89.

301. Koizumi H, Hashimoto K, Itoh K, Nakazato M, Shimizu E, et al. (2004) Association between the brain-derived neurotrophic factor 196G/A polymorphism and eating disorders. Am J Med Genet B Neuropsychiatr Genet 127B: 125-127.

302. Ribasés M, Gratacòs M, Armengol L, de Cid R, Badía A, et al. (2003) Met66 in the brain-derived neurotrophic factor (BDNF) precursor is associated with anorexia nervosa restrictive type. Mol Psychiatry 8: 745-751.

303. Ribasés $M$, Gratacòs M, Fernández-Aranda F, Bellodi L, Boni $C$, et al. (2004) Association of BDNF with anorexia, bulimia and age of onset of weight loss in six European populations. Hum Mol Genet 13: 1205-1212.

304. Gerken T, Girard CA, Tung YC, Webby CJ, Saudek V, et al. (2007) The obesity-associated FTO gene encodes a 2-oxoglutarate-dependent nucleic acid demethylase. Science 318: 1469-1472.

305. Boender AJ, van Rozen AJ, Adan RA (2012) Nutritional state affects the expression of the obesity-associated genes Etv5, Faim2, Fto, and Negr1. Obesity (Silver Spring) 20: 2420-2425.

306. Vujovic P, Stamenkovic S, Jasnic N, Lakic I, Djurasevic SF, et al. (2013) Fasting induced cytoplasmic Fto expression in some neurons of rat hypothalamus. PLoS One 8: e63694.

307. Fischer J, Koch L, Emmerling C, Vierkotten J, Peters T, et al. (2009) Inactivation of the Fto gene protects from obesity. Nature 458: 894-898.

308. Tanofsky-Kraff M, Han JC, Anandalingam K, Shomaker LB, Columbo KM, et al. (2009) The FTO gene rs9939609 obesity-risk allele and loss of control over eating. Am J Clin Nutr 90: 1483-1488.

309. Müller TD, Greene BH, Bellodi L, Cavallini MC, Cellini E, et al. (2012) Fat mass and obesity-associated gene (FTO) in eating disorders: evidence for association of the rs 9939609 obesity risk allele with bulimia nervosa and anorexia nervosa. Obes Facts 5: 408-419.

310. Jonassaint CR, Szatkiewicz JP, Bulik CM, Thornton LM, Bloss C, et al. (2011) Absence of association between specific common variants of the obesity-related FTO gene and psychological and behavioral eating disorder phenotypes. Am J Med Genet B Neuropsychiatr Genet 156: 454-461.

311. Branson R, Potoczna N, Kral JG, Lentes KU, Hoehe MR, et al. (2003) Binge eating as a major phenotype of melanocortin 4 receptor gene mutations. N Engl J Med 348: 1096-1103.

312. Potoczna N, Branson R, Kral JG, Piec G, Steffen R, et al. (2004) Gene variants and binge eating as predictors of comorbidity and outcome of treatment in severe obesity. J Gastrointest Surg 8: 971-981.

313. Wardlaw SL (2011) Hypothalamic proopiomelanocortin processing and the regulation of energy balance. Eur J Pharmacol 660: 213-219.

314. Hinney A, Volckmar AL (2013) Genetics of eating disorders. Curr Psychiatry Rep 15: 423.

315. Trace SE, Baker JH, Peñas-Lledó E, Bulik CM (2013) The genetics of eating disorders. Annu Rev Clin Psychol 9: 589-620. 